OPEN ACCESS

Edited by:

William Cho,

Queen Elizabeth Hospital (QEH),

Hong Kong

Reviewed by:

Bradley Doble,

McMaster University, Canada

Paola Rizzo,

University of Ferrara, Italy

${ }^{*}$ Correspondence:

Maria Pelullo

Maria.Pelullo@iit.it

Diana Bellavia

diana.bellavia@uniroma1.it

Specialty section:

This article was submitted to

Stem Cell Research,

a section of the journal

Frontiers in Genetics

Received: 13 March 2019

Accepted: 05 July 2019

Published: 21 August 2019

Citation:

Pelullo M, Zema S, Nardozza F,

Checquolo S, Screpanti I and

Bellavia D (2019) Wnt, Notch,

and TGF- $\beta$ Pathways Impinge on

Hedgehog Signaling Complexity: An

Open Window on Cancer.

Front. Genet. 10:711.

doi: 10.3389/fgene.2019.00711

\section{Wnt, Notch, and TGF- $\beta$ Pathways Impinge on Hedgehog Signaling Complexity: An Open Window on Cancer}

\author{
Maria Pelullo ${ }^{*}$, Sabrina Zema ${ }^{2}$, Francesca Nardozza ${ }^{2}$, Saula Checquolo ${ }^{3}$, \\ Isabella Screpanti ${ }^{2}$ and Diana Bellavia ${ }^{2 *}$ \\ ${ }^{1}$ Center of Life Nano Science Sapienza, Istituto Italiano di Tecnologia, Rome, Italy, ${ }^{2}$ Department of Molecular Medicine, Sapienza \\ University, Rome, Italy, ${ }^{3}$ Department of Medico-Surgical Sciences and Biotechnologies, Sapienza University, Latina, Italy
}

Constitutive activation of the Hedgehog $(\mathrm{Hh})$ signaling pathway is associated with increased risk of developing several malignancies. The biological and pathogenic importance of $\mathrm{Hh}$ signaling emphasizes the need to control its action tightly, both physiologically and therapeutically. Evidence of crosstalk between $\mathrm{Hh}$ and other signaling pathways is reported in many tumor types. Here, we provide an overview of the current knowledge about the communication between $\mathrm{Hh}$ and major signaling pathways, such as Notch, Wnt, and transforming growth factor $\beta$ (TGF- $\beta$ ), which play critical roles in both embryonic and adult life. When these pathways are unbalanced, impaired crosstalk contributes to disease development. It is reported that more than one of these pathways are active in different type of tumors, at the same time. Therefore, starting from a plethora of stimuli that activate multiple signaling pathways, we describe the signals that preferentially converge on the $\mathrm{Hh}$ signaling cascade that influence its activity. Moreover, we highlight several connection points between $\mathrm{H}$ h and Notch, Wnt, or TGF- $\beta$ pathways, showing a reciprocal synergism that contributes to tumorigenesis, supporting a more malignant behavior by tumor cells, such as in leukemia and brain tumors. Understanding the importance of these molecular interlinking networks will provide a rational basis for combined anticancer drug development.

Keywords: Hedgehog, Notch, Wnt, TGF- $\beta$, signaling pathway, tumorigenesis

\section{INTRODUCTION}

Signaling pathways are networks of regulatory proteins and other gene products that act in a coordinated manner to control various biological processes inside the cell. Remarkably, mutation of a single gene encoding a component of a specific pathway is able to affect related signaling cascades, triggering unbalanced crosstalk that leads to cancer development. Of note, impaired regulation of primary signaling pathways can ultimately culminate in constitutive activation of signaling effectors in the nucleus, where they act out of control, sustaining the expression of pro-tumoral target genes. To date, it is known that tumor development is characterized by deregulation of at least two major signaling pathways at the same time, which crosstalk with each other, determining the acquisition of malignant phenotypes (Petrova and Joyner, 2014). 
Hedgehog $(\mathrm{Hh})$ signaling is a critical pathway that mainly controls embryonic development, whereas in post-natal life, it is inactive or poorly active, playing a restricted role in stem cell maintenance and tissue homeostasis/repair (Petrova and Joyner, 2014). Since Hh signaling regulates a wide array of biological activities in various cell types, its misregulation is responsible for the development of many types of cancers. Studies show that the mutational activation of Hh signaling is a nodal point in sustaining tumorigenic programs, ranging from the tumor initiation to tissue invasion/metastasis and chemoresistance, in several different tumors.

Of note, recent studies show that Hh signaling elements talk to several other cofactors belonging to major pathways, such as Notch, Wnt, and transforming growth factor $\beta$ (TGF- $\beta$ ), resulting in significant crosstalk between these signaling networks. The integration of several signaling pathways is a key step able to determine a more aggressive behavior of tumor cells and their resistance to pharmacological approaches. Interestingly, Notch, Wnt, and TGF- $\beta$ pathways are able to promote/sustain oncogenesis through synergistic associations with Hh signaling in several types of tumors.

Here, we review a global picture of intricate protein-protein interaction networks between key components of Hedgehog, Wnt, Notch, and TGF- $\beta$ signaling pathways in an unbalanced/malignant context. We also describe how these main pathways can integrate with each other and ultimately affect Hh signaling output.

\section{THE HEDGEHOG PATHWAY}

First discovered in Drosophila, Hedgehog signaling is an evolutionarily conserved pathway that plays a key role as a morphogenesis driver for embryonic and post-natal development.
It regulates diverse cellular processes, including cell proliferation, tissue differentiation, and repair of normal tissues (NussleinVolhard and Wieschaus, 1980; Napolitano et al., 1999; Varjosalo and Taipale, 2008), and it is also implicated in regulation/survival of normal and malignant stem cells (Liu et al., 2006; Merchant and Matsui, 2010). Canonical Hedgehog pathway activation is characterized by the interaction of Hh ligands, Sonic (SHh), Indian (IHh), and Desert (DHh), to the Patched1 (Ptch1) receptor, which resides in the primary cilium (PC) (Rohatgi et al., 2007; Wong and Reiter, 2008). Interestingly, the PC is a key organelle that consists of microtubules emanating from the cell surface in which SHh signaling takes place, and it responds to mechanical stimuli in the micro-environment (Michaud and Yoder, 2006). In the absence of Hh ligand, Ptch localizes to the base of the PC and catalytically represses the activity of the transducer Smoothened (SMO) (Burns et al., 2018), a member of G-protein-coupled receptor-like (GPCR), by inhibiting its translocation into the PC (Denef et al., 2000) (Figure 1A). SMO is a seven-transmembrane-span receptor-like protein that is confined to intracellular endocytic vesicles when the $\mathrm{Hh}$ pathway is switched off (Taipale et al., 2002). Hh binding both causes the internalization of ligand/receptor complex from the cell surface towards lysosomes, where the proteins are degraded (Mastronardi et al., 2000), and promotes the accumulation of SMO at the cell surface (Denef et al., 2000). Once activated, SMO is hyperphosphorylated by casein kinase 1 (CK1) and G-proteincoupled receptor kinase 2 (GRK2), resulting in the release of its inhibition, and at this point, it is free to move from the base into the tip of the PC (Denef et al., 2000; Chen et al., 2011) (Figure 1B). Given these features, SMO is considered a positive regulator of the Hh signaling pathway because, when it is constitutively activated, it stimulates downstream components of the signaling pathway. Therefore, the ligand/receptor complex relieves the SMO

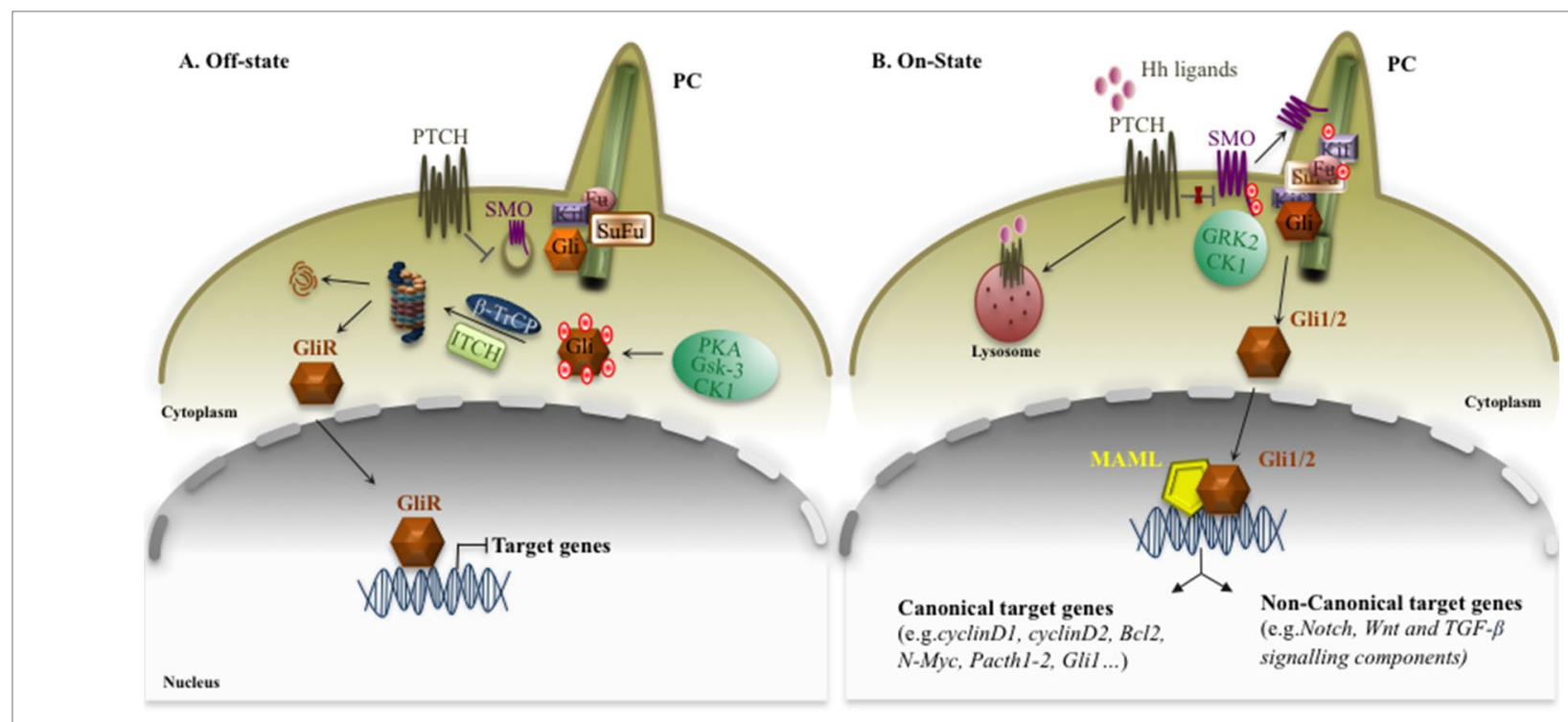

FIGURE 1 | Canonical Hh signaling. The canonical Hh signaling pathway in off (panel A) or on (panel B) state. The figure is widely discussed in the text. The red dots represent post-translational modifications: phosphorylation. 
inhibition and triggers a cascade of intracellular processes that involve a dynamic association between Gli transcription factors, the final effectors of $\mathrm{Hh}$ signaling, and Suppressor of Fused $(\mathrm{SuFu})$. Unlike $\mathrm{SMO}, \mathrm{SuFu}$ is considered a tumor suppressor gene and a negative regulator of Hedgehog signaling, able to bind directly to Gli proteins to regulate their activity, processing, and localization, (Ryan and Chiang, 2012), by sequestering them in the cytosol (Ding et al., 1999; Dunaeva et al., 2003) or regulating their affinity to DNA (Pearse et al., 1999; Stone et al., 1999; Sisson et al., 2006). However, the specific mechanisms concerning Gli inactivation by $\mathrm{SuFu}$ are not completely understood (Carballo et al., 2018). Hh ligand binding sustains the release of Gli from $\mathrm{SuFu}$ that moves into the nucleus and activates $\mathrm{Hh}$ target genes. Altogether, these molecular events sustain the signal that is transduced from the ligand/receptor complex to the downstream transcription factors (Gli1, Gli2, and Gli3), which in turn translocate into the nucleus and regulate the expression of Hh target genes, including Gli1 itself. Prominently, Gli1 is both the downstream effector and a target gene of the pathway, representing a feedback loop that serves as a readout of Hh activity (Sasaki et al., 1999; Regl et al., 2002). Interestingly, Glil consists of zinc finger and C-terminal activator domains, whereas Gli2 and Gli3 also possess an $\mathrm{N}$-terminal repressor domain. On the basis of these structural differences, Glil functions exclusively as a transcriptional activator, whereas Gli2 and Gli3 exist as full-length (FL) activator and truncated repressor (GliR) forms, displaying in this way both positive and negative transcriptional functions (Lee et al., 1997; Dai et al., 1999; Sasaki et al., 1999; Bai et al., 2004). In the absence of Hh ligand, GliFL is phosphorylated by protein kinase-A (PKA), glycogen synthase kinase-3 (GSK3), and CK1 (Price and Kalderon, 2002), and recognized by $\beta$-transducin-repeat containing protein $(\beta$-TrCP), which is able to partially degrade Gli proteins in truncated forms (Glis). At this point, Gli proteins retained at the cytoplasm by $\mathrm{SuFu}$ are degraded, inhibiting SHh signaling (Humke et al., 2010). These events lead to proteolytic cleavage of GliFL into C-terminally truncated repressor form, GliR, which translocates to the nucleus, where it binds to Hh target gene promoters and keeps them switched off (Goetz and Anderson, 2010). Interestingly, a recent paper shows that the Itch/ $\beta$-arrestin 2 complex binds $\mathrm{SuFu}$ and induces its polyubiquitination without any impact on stability, but sustaining the conversion of Gli3 into a repressor, which is able to switch off the signal (Infante et al., 2018).

Under basal conditions, Glil activity can be controlled by proteasome degradation, mediated by two distinct ubiquitindependent processing pathway E3 ubiquitin ligases, $\beta$-TrCP and Itch, able to inactive Gli1 in the cytosol (Lee et al., 1997; Di Marcotullio et al., 2006; Di Marcotullio et al., 2007; Di Marcotullio et al., 2011; Infante et al., 2016). On the contrary, the activation of $\mathrm{Hh} / \mathrm{Gli}$ signaling is associated with a translocation of Gli1 into the nucleus, where it exerts strong mitogenic and prosurvival activities. Another mechanism able to control the Hh signaling is based on the acetylation status of Gli1 and Gli2, mediated by Histone deacetylases (HDACs). Indeed, HDAC-mediated deacetylation promotes transcriptional activation and sustains a positive regulatory loop. This mechanism is turned off by HDAC1 degradation, mediated by a Cullin3/Ren complex (Canettieri et al., 2010).
Recent studies identify Mastermind-like 1 (Maml1) as a novel positive regulator of $\mathrm{Hh}$ signaling. It physically interacts with Gli proteins (Gli1 and Gli2), working as a potent transcriptional coactivator (Quaranta et al., 2017; Vied and Kalderon, 2009), empowering Gli-mediated transcriptional activity. Finally, Gli1 activation induces the transcription of $\mathrm{Hh}$ target genes involved in key cellular processes, such as the cell cycle (Cyclin D1 and D2) (Sasaki et al., 1999), apoptosis (Bcl2) (Bigelow et al., 2004), N-Myc (Oliver et al., 2003), various transcription factors and components of the Hh pathway itself such as Ptch1, Ptch2, and Gli1 for negative and positive feedback loop mechanisms (canonical target genes) (Bonifas et al., 2001; Oliver et al., 2003, Vokes et al., 2007; Coni et al., 2013), and elements of other pathways such as Notch1 and Jagged1 (Stecca and Ruiz i Altaba, 2009), Hes1 (Ingram et al., 2008; Wall et al., 2009), Wnt signals (Mullor et al., 2001), and TGF- $\beta$ members (Fan et al., 2010) (non-canonical target genes), suggesting that the Hh signaling pathway can integrate with elements of major signaling pathways (Figure 1).

\section{HEDGEHOG MUTATIONS AND DISEASE}

Mutational activation of the Hh signaling pathway is tightly linked to maintenance of tumor-initiating stem cells, tumorigenesis, and tumor invasiveness in several types of cancer (Nilsson et al., 2000; Varnat et al., 2009; Harris et al., 2012). Mutations in Hh signaling can be classified as loss of function (i.e., Ptch1 and $\mathrm{SuFu}$ ) or gain of function (i.e., Gli1, Gli2, and SMO), both associated with an aberrant activation of the Hh pathway (Table 1). Constitutive Hh signaling triggers a strong cellular mitogenic response that ultimately predisposes to abnormal proliferation leading to tumorigenesis.

Notably, it is known that patients with Gorlin syndrome (GS), also called nevoid basal cell carcinoma syndrome (nevoid BCC) or basal cell nevus syndrome, are predisposed to multiple cancers, including basal cell carcinoma (BCC), medulloblastoma (MB), and rhabdomyosarcoma (Johnson et al., 1996; Jones et al., 2011). Gorlin syndrome patients carry mutations in Ptch1 and SuFu genes (Hahn et al., 1996; Smith et al., 2014). Of note, SuFu germline mutations are present with a low frequency (Smith et al., 2014). By contrast, heterozygous germline mutations in Ptch1, including nonsense, missense, splicing mutations, as well as loss of heterozygosity (LOH) (Burns et al., 2018), are typical alterations in these patients, inducing different tumors (Lindstrom et al., 2006). In patients with GS, the loss of function of the Ptch1 gene permits SMO to move into the PC, resulting in an aberrant activation of Hh signaling, which drives cellular growth of these tumors. Notably, the Ptch1 knock-out mouse model develops tumors similar to Gorlin syndrome patients, like BCC, MBs, and sporadic rhabdomyosarcomas, providing evidence about the driver role of Hh signaling for cancer development (Hahn et al., 1996; Nitzki et al., 2011). The co-presence of Ptch1 and SuFu mutations or Gli1 amplifications is also identified in rhabdomyosarcoma patients (Bridge et al., 2000; Roberts et al., 1989). Finally, combined heterozygous Ptch1 and Ptch 2 germline mutations are observed in newborns with rhabdomyosarcoma (Taeubner et al., 2018), suggesting that haploinsufficiency of Ptch is sufficient to sustain 
tumor development in the absence of LOH (Nilsson et al., 2000). In addition, $\mathrm{MB}$ is one the most common brain tumors affecting mostly children and is a typical GS-related cancer (Jones et al., 2011; Huttner, 2012). GS patients characterized by SuFu mutations display a higher risk of developing MB than Ptch1-mutated patients. Based on the molecular features that are involved in $\mathrm{MB}$ pathogenesis, it is possible to distinguish four groups: SHh-activated, WNT-activated, c-Myc-activated, and Group 4 associated with isochromosome 17q (Kool et al., 2012; Rusert et al., 2014). In MB, Hh-dependent tumorigenesis may depend on an aberrant regulation of Hh ligands or a deregulation of $\mathrm{Hh}$ signaling with an altered expression/function of downstream components, such as loss-of-function mutations of Ptch1 or SUFU (Taylor et al., 2002; Kool et al., 2012) or, conversely, activating mutations of SMO and SHh (Reifenberger et al., 1998; Zurawel et al., 2000). Of note, somatic copy number variations of Gli1 and Gli2 genes are found in this subgroup (Thompson et al., 2006; Northcott et al., 2009). All these mutations allow ligand-independent $\mathrm{Hh}$ signaling to promote cell growth and increase tumorigenesis.

Alterations in $\mathrm{Hh}$ signaling are also described in meningiomas, the most common primary tumor of the central nervous system (Wiemels et al., 2010). Aavikko and colleagues identified a germline $S u F u$ mutation as the cause of multiple meningiomas in a single large Finnish family, suggesting that $\mathrm{SuFu}$ alterations predispose to meningiomas in addition to MBs (Aavikko et al., 2012).

BCC is a common type of skin cancer, representing almost $80 \%$ of non-melanoma skin cancer (NMSC), with an incidence that increases by $10 \%$ per year (Bakshi et al., 2017). As argued above, BCC is linked to GS and is characterized by germline mutations of Ptch1 and SuFu. Accordingly, sporadic BCC presents hyperactivated $\mathrm{Hh}$ signaling, associated with inactivating mutations in Ptch1 and activating mutations in SMO, with a high-rate frequency (Gailani et al., 1996; Reifenberger et al., 1998; Xie et al., 1998). Moreover, loss of SuFu function is also found in sporadic BCC (Reifenberger et al., 2005). Couvè-Privat and colleagues identify the presence of ultraviolet (UV)-specific mutations in the NH2-terminal domain of SHh in BCC patients with xeroderma pigmentosum (Couve-Privat et al., 2004). The current opinion is that during BCC genesis, SHh signaling aberrantly activated is necessary, maybe sufficient, to develop the malignancy (Teglund and Toftgard, 2010). In addition, there are numerous types of cancer associated with $\mathrm{Hh}$ signaling activation. Genetic aberrations on Hh signaling are found also in a subset of breast cancer, characterized by loss of function in Ptch1 and gain of function of Gli1 (Naylor et al., 2005; Nessling et al., 2005; Wood et al., 2007; Sinha et al., 2008; Jiao et al., 2012). A global genomic analysis from twenty-four advanced pancreatic adenocarcinomas highlighted the presence of missense mutations in Gli1 and Gli3 (Jones et al., 2008), and Hh signaling pathway is recognized as an early and late mediator of pancreatic cancer tumorigenesis (Thayer et al., 2003). Also, in prostate cancer is identified a SuFu mutation (Sheng et al., 2004). Recently, in patients with T-cell acute lymphoblastic leukemia (T-ALL), several mutations of SHh signaling are described (Dagklis et al., 2016), and loss of Ptch1 function is able to empower T-ALL development
Notch1-dependent, demonstrating that Hh pathway activation is an oncogenic driver in the molecular pathogenesis of T-ALL (Burns et al., 2018). In addition, SMO and Ptch1 mutations are also found in gastrointestinal tumors (Guleng et al., 2006; Wang et al., 2013). Lee and colleagues performed a single-strand conformation polymorphism analysis and DNA sequencing in samples of colorectal and gastric cancers and identified frameshift mutations of Gli1, associated with a microsatellite instability (MSI) phenotype. (Lee et al., 2018). Finally, SMO activating mutations are involved in ameloblastomas arising in the maxilla (Sweeney et al., 2014).

Although tumors not GS-related present direct mutations in genes involved in the Hh pathway, it is not possible to identify $\mathrm{Hh}$ signaling as the driving force for cancer onset. In fact, activated Hh signaling is able to empower the severity of the tumors, but this pathway alone is not capable of driving cancer development. A major elucidation of the mechanisms leading to the genesis of malignancy through an aberrant activation of this pathway and/ or unbalanced cross-talking with other signaling pathways could provide additional therapeutic options to limit tumor growth and relapse and to reduce drug resistance.

\section{COMMUNICATION AMONG HH AND DIFFERENT SIGNALING PATHWAYS}

\section{Crosstalk Between Hh and Notch Signaling Pathways}

The family of Notch receptors includes four heterodimeric transmembrane proteins (Notch1-4), which are activated upon interaction with different types of ligands [Serrate-like Jagged1 and 2 (JAG1-2) and Delta-like (Delta1, 3, and 4)], expressed by adjacent cells. The activation of Notch signaling requires the binding in trans between Notch receptors, expressed on the surface of signal-receiving cells, and Notch ligands, expressed on the surface of adjacent signal-sending cells. Such an interaction renders Notch susceptible to two sequential proteolytic cleavages that involve two distinct enzymes: an A-disintegrin and metalloprotease (ADAM) and Presenilin (PS) $/ \gamma$-secretase complex. These events end in the release of a soluble Notch intracellular domain (NICD) (Mumm and Kopan, 2000; Fortini, 2009; Kopan and Ilagan, 2009; Palermo et al., 2014; Bellavia et al., 2018). In canonical Notch signaling, NICD disengages from the plasma membrane and proceeds towards the nucleus, where it associates with recombining binding protein suppressor of hairless J kappa (RBP-Jк, also known as RBPSUH/ CSL/CBF-1), a transcription repressor. CSL-NICD complex, reached by a member of Mastermind-family coactivators (MAML1-3) (Wu et al., 2000), induces the transcriptional activation of several target genes, for instance, HES1/5, HEY (Bellavia et al., 2018), Myc (Palomero et al., 2006; Weng et al., 2006), cyclinD (Joshi et al., 2009; Cohen et al., 2010), pTalpha (Bellavia et al., 2007b), and Jagged1 (Pelullo et al., 2014). Notch signaling activation also occurs in a non-canonical pathway. NICD can coactivate transcription by forming a complex with the lymphoid enhancer factor 1 (LEF-1) transcription factor (Ross and Kadesch, 2001) or by binding to p50 or c-Rel in 
the nucleus to enhance the activity of the transcription factor NF- $\kappa$ B (Nuclear Factor-kappa B) (Shin et al., 2006; Vacca et al., 2006; Kumar et al., 2014), and can modulate Tal-1 and/ or Ikaros activity (Beverly and Capobianco, 2003; Campese et al., 2003; Talora et al., 2006; Bellavia et al., 2007a; Talora et al., 2008). Notch signaling, like the Hh pathway, is involved in the proliferation, differentiation, and survival of multiple tissues. In the hematopoietic system, Notch can increase the survival and self-renewal of hematopoietic progenitors (Varnum-Finney et al., 2000) and controls regulatory T-cell expansion/migration to peripheral lymphoid organs (Campese et al., 2009; Ferrandino et al., 2018a; Ferrandino et al., 2018b). Very intriguing is the observation that Notch1 and Notch3 receptors are associated with different steps of ongoing thymocyte development (Felli et al., 1999). This suggests that they work with distinct timing and with separate spatial expression, underlining the absence of a functional redundancy, an observation sustained also by structural differences (Bellavia et al., 2018). A hampered Notch signaling pathway takes place in several pathological events that range from neurodegenerative disorders to cancer (Joutel et al., 2000). Persistent uncontrolled Notch signaling is responsible for the onset/progression of several tumors, such as T-cell leukemia (Checquolo et al., 2010; Cialfi et al., 2013; Vargas Romero et al., 2015; Franciosa et al., 2016; Tottone et al., 2019), B-cell leukemia (Rosati et al., 2009; Arruga et al., 2014; De Falco et al., 2015), breast cancer (Rustighi et al., 2014; Diluvio et al., 2018), colorectal (Reedijk et al., 2008; Sikandar et al., 2010), ovarian cancer (Choi et al., 2008; Steg et al., 2011; McAuliffe et al., 2012), glioma (Catanzaro et al., 2017; Ceccarelli et al., 2019), and skin cancer (Cialfi et al., 2014; Palermo et al., 2014). Numerous gainof-function mouse models show that mutations in Notch1/3 signaling are related to rare cases of human T-ALL (Bellavia et al., 2000; Allman et al., 2001). Although first associated with T-ALL, activating Notch mutations are identified in several subtypes of B-cell malignancies (Micci et al., 2007; Rosati et al., 2009; Kuang et al., 2013; Radojcic and Maillard, 2014; De Falco et al., 2018).

Studies show that Notch and Hh signaling pathways share the exact spatio-temporal window during T-cell development even if they play a non-redundant role in orchestrating early thymocyte differentiation and proliferation before pre-T cell Receptor (pre- TCR) signal initiation (Crompton et al., 2007; Rowbotham et al., 2007; Drakopoulou et al., 2010). These findings suggest that Hh may synergize with Notch signaling to maintain an intracellular balance through a significant integration of these signaling pathways. It is known that aberrant $\mathrm{Hh}$ signaling contributes to tumor cell growth and survival and cancer stem cell (CSC) maintenance in lymphomas, leukemia, multiple myeloma, and B-cell chronic lymphocytic leukemia (CLL) (Dierks et al., 2007; Lindemann, 2008; Singh et al., 2010; Decker et al., 2012; Aberger et al., 2017). To unravel the molecular mechanisms that subtend in the network of cross-talking pathways could be essential in treatment of hematological disease. Interestingly, $\mathrm{Hh}$ signaling is a potential therapeutic target for patients with myeloid and lymphoid leukemia, and Hh pathway inhibitors are used in many preclinical studies (Dagklis et al., 2016; Rimkus et al., 2016). Despite the importance of the Hh pathway in T-cell development and in several hematological malignancies
(Mar et al., 2011), the role of the Hh pathway in T-ALL is unclear, and conflicting data are reported. A study shows that Hedgehog signaling is dispensable for T-ALL development (Gao et al., 2009), whereas other studies document T-ALL cell line sensitivity to Hh inhibitors, suggesting that this pathway may be important in T-ALL development and/or maintenance (Ji et al., 2007; Hou et al., 2014; Dagklis et al., 2016). Recently, several reports highlight activating mutations in components of the $\mathrm{Hh}$ signaling in T-ALL, supporting the idea that Hedgehog pathway deregulation may play a role in the onset and/or development of T-ALL. Functional analysis confirms the gain-of-function properties of two truncated SMO mutations in T-ALL (Dagklis et al., 2015). Moreover, primary T-ALL cases with high Gli mRNA levels are sensitive to Hedgehog pathway inhibition by GANT61 or vismodegib in in vivo xenograft models (Hou et al., 2014; Dagklis et al., 2016). Despite the numerous correlations, the existence of a direct molecular connection between $\mathrm{Hh}$ and Notch in T-ALL is not well documented, yet. Recently, it has been reported that loss of Ptch1 function is able to accelerate the onset of Notch1-induced human T-ALL, demonstrating that Hh pathway mutations are driver oncogenic alterations, providing a molecular rationale for targeted therapy (Burns et al., 2018).

On the contrary, a reciprocal exclusion between $\mathrm{Hh}$ and Notch signaling pathways is already defined in the skin. In particular, Notch1 deficiency results in an increased expression of Gli2, along with tumor development in squamous cell carcinoma (Okuyama et al., 2008).

Likewise, an inverted gradient between $\mathrm{Hh}$ and Notch is observed in normal colon crypt development (Kosinski et al., 2007; Takebe et al., 2011; Geissler and Zach, 2012). Very little is known regarding the crosstalk mechanisms between $\mathrm{Hh}$ and Notch in colorectal cancer (CRC) tumorigenesis and progression. A paper shows an antagonistic crosstalk between $\mathrm{Hh}$ and Notch in order to give rise to proper intestine organogenesis in the mouse, but the molecular mechanism is unknown (Kim et al., 2011). Moreover, interaction between Notch and Hedgehog signaling pathways is critical in regulating self-renewal, proliferation, and differentiation of target cells, ensuring correct organogenesis. Numerous evidence supports the significant role of $\mathrm{Hh} /$ Notch crosstalk in cancer biology and chemotherapy-resistant CSCs (Takebe et al., 2011). Studies suggest that crosstalk between $\mathrm{Hh}$ and Notch signaling pathways exists and may be involved in the regulation of embryonic stem cell fate determination (Huang et al., 2012), in self-renewal and differentiation of breast cancer cells (Guo et al., 2011), and in hepatic stellate cell fate (Xie et al., 2013). In addition, a study provides evidence that Notch signaling regulates the expression of SHh in neuronal stem cells. Notch activation leads to expression of Hes3 and SHh through activation of serine/threonine protein kinase B (Akt), signal transducer and activator of transcription 3 (STAT3), and mammalian target of rapamycin (mTOR), which promote cell survival (Androutsellis-Theotokis et al., 2006). Conversely, Gli1 is able to sustain the transcription of Jagged 1 and Notch1 in the brain (Stecca and Ruiz i Altaba, 2009), and Notch ligand Jagged2 (Katoh and Katoh, 2009). On the other hand, the Notch target Hes1, a repressive transcription factor, is able to suppress Hh signaling, by inhibiting Gli1 transcription in glioma and MB tumors (Schreck et al., 2010). Of note is the observation that Hes1, the principal effector 
of the Notch pathway, is also a target of SHh in both in mesodermal and neural cells (Ingram et al., 2008). These data agree with the observation that in a subset of MB patients, Hes1 is upregulated and its expression correlates with shorter patient survival (Fan et al., 2004). Combined activation of $\mathrm{Hh}$ and Notch signaling pathways is observed in prostate cancer cells (Domingo-Domenech et al., 2012) and in the pathogenesis of pituitary adenomas (Yavropoulou et al., 2015). Furthermore, novel mechanistic insights demonstrate that Notch signaling plays a central role in left-right asymmetry, playing a crucial role in regulating cilium length (Krebs et al., 2003, Lopes et al., 2010). Interestingly, Notch signaling controls trafficking of Hh signaling mediators into the PC, sustaining the responsiveness to SHh (Kong et al., 2015, Stasiulewicz et al., 2015). Consistent with this observation, Notch and Presenilin 2, a subunit of the $\gamma$-secretase complex, localize around the PC. Notch signaling is activated by presenilin $/ \gamma$-secretase activity, and the Notch intracellular domain is able to move into the nucleus to activate the transcription of several genes involved in cilium length and Hh signaling (Ezratty et al., 2011, Stasiulewicz et al., 2015). This phenomenon could be explained by the observation that the NICD/RBP-JK complex is able to drive the transcriptional activation of SMO and Gli2/3 in neuronal cells (Li et al., 2012) (Figure 2).
However, the existence of a regulatory mechanism impinging on the crosstalk between $\mathrm{Hh}$ and Notch in controlling tumor onset and progression needs to be better understood.

\section{Crosstalk Between Hh and Wnt/ $\beta$-Catenin Signaling Pathways}

The Wnt family of secreted glycoproteins governs multiple developmental events during embryogenesis via the transcriptional coactivator $\beta$-catenin, and it is also implicated in adult tissue homeostasis and repair (Logan and Nusse, 2004).

In the absence of Wnt proteins, the cytoplasmic $\beta$-catenin protein is constantly degraded by the action of a $\beta$-catenin degradation complex, composed of the tumor suppressor adenomatous polyposis coli gene product (APC) (MacDonald et al., 2009), the scaffolding protein Axin, CK1, and GSK3. Together, these proteins induce post-translational modifications, resulting in a phosphorylated $\beta$-catenin, which is recognized by $\beta$-TrCP, targeted for ubiquitination and degraded by the proteasome (He et al., 2004). Altogether, these events prevent a $\beta$-catenin shift into the nucleus, and $W n t / \beta$-catenin target genes are thereby repressed by the T-cell factor (TCF)/LEF family of proteins (Brannon et al., 1997),

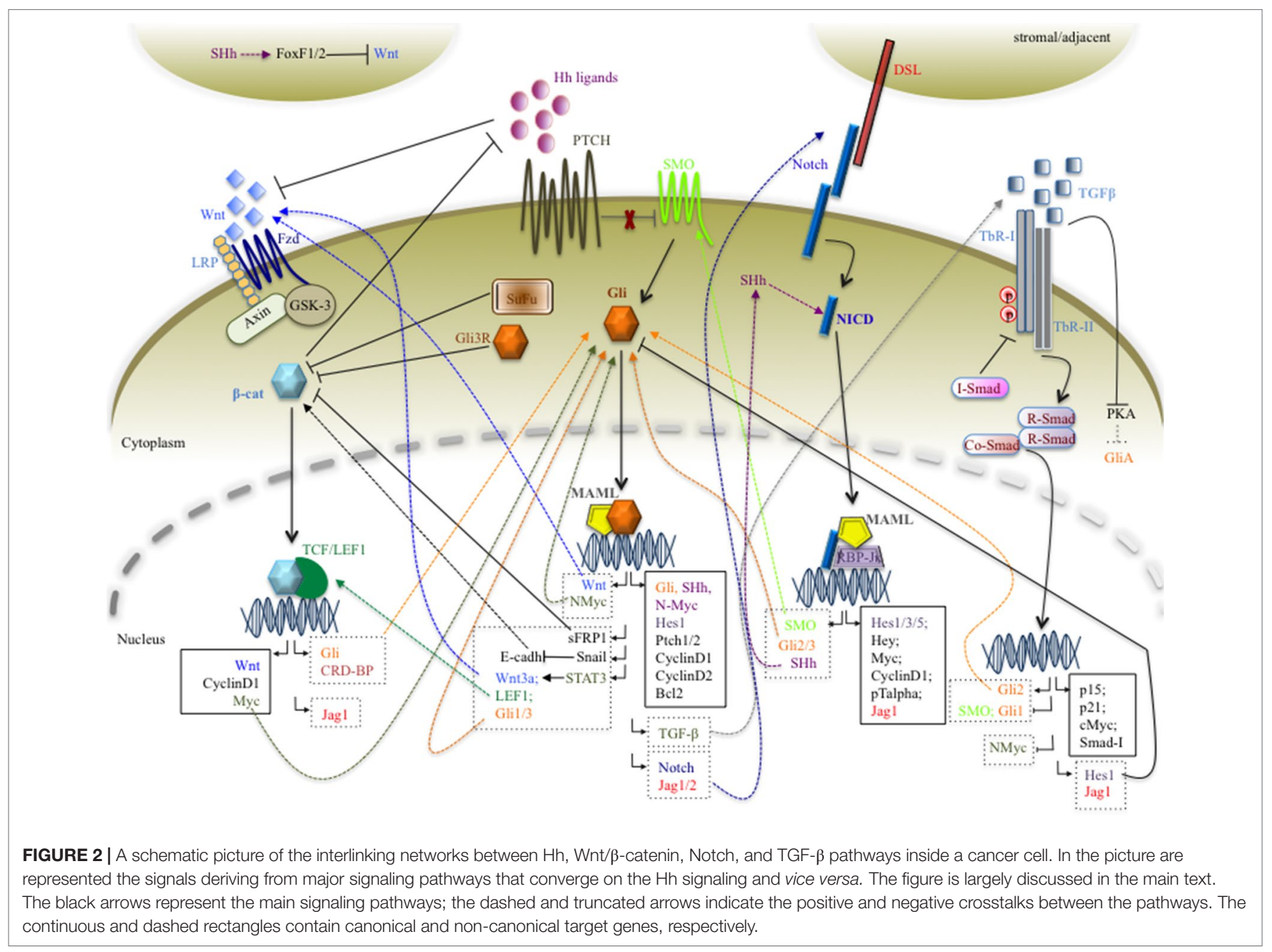


associated with the transcriptional repressor Groucho/Transducinlike enhancer protein (TLE) (Cavallo et al., 1998). The Wnt/ $\beta$-catenin pathway is activated when a Wnt ligand binds to the seven-pass transmembrane Frizzled (Fz or Fzd) receptor, linked to (Brannon et al., 1997) its coreceptor, the low-density lipoprotein receptorrelated protein (LRP). Upon the employment of the scaffolding protein Dishevelled (Dvl), the Wnt-Fz-LRP complex induces the recruitment of the Axin complex to the receptors. These events lead to inhibition of Axin-mediated $\beta$-catenin phosphorylation and thereby to the stabilization of $\beta$-catenin, which accumulates and moves to the nucleus. Once there, $\beta$-catenin-converts the TCF/ Groucho/TLE repressor complex into a transcriptional activator complex that activates the expression of Wnt target genes, such as Wnt components (MacDonald et al., 2009), c-Myc (He et al., 1998), Cyclin D1 (Tetsu and McCormick, 1999), and the Notch ligand Jagged1 (Rodilla et al., 2009) (Figure 2). Oncogenic mutations in canonical Wnt signaling determine a constitutive activation of the pathway in a ligand-independent manner, which is linked to human congenital disorders, cancers, and other diseases (Clevers, 2006). Moreover, a recent review summarizes the wide range of epigenetic modifications of the Wnt signaling pathway that affects the development of a variety of tissues and organs, producing dramatic phenotypes and sustaining tumor formation (Wils and Bijlsma, 2018).

Recent studies show that $\mathrm{Hh}$ and Wnt signaling pathways can regulate each other, affecting their transcriptional output in specific cellular contexts in which they normally operate (Figure 2). Firstly, a crosstalk between $\mathrm{Hh}$ and Wnt signaling pathways is described to be involved in the onset/progression of BCC. In fact, aberrant Hh signaling activation, the key step in the tumorigenic program leading to BCC (Nilsson et al., 2000), determines the transcriptional activation of Wnt genes through Gli transcription factors (Bonifas et al., 2001; Katoh and Katoh, 2009). Moreover, the existence of a positive feedback loop between $\mathrm{Hh}$ and Wnt is present during epithelial transformation, where Glil activates Snail, which in turn maintains Glil expression through Wnt/ $\beta$-catenin signaling (Li et al., 2007).

Several reports demonstrate the existence of two-way communication between $\mathrm{Hh}$ and Wnt. On one hand, $\beta$-catenin is able to directly enhance the luciferase activity of Gli-responsive elements (Maeda et al., 2006) and to induce the post-transcriptional stabilization of Gli mRNAs, by upregulating CRD-BP, (coding region determinant-binding protein), an RNA-binding protein (Noubissi et al., 2009). On the other hand, Gli1 is able to induce the activation of Wnt2b, Wnt4, and Wnt7b, which in turn trigger Wnt $/ \beta$-catenin signaling by promoting the stability of $\beta$-catenin itself ( $\mathrm{Li}$ et al., 2007). In keeping with these experimental data, the inhibition of Hh signaling by cyclopamine reduces $\beta$-catenin/ TCF transcriptional activity, induces E-cadherin expression, and reduces invasion in CRC (Qualtrough et al., 2015). Moreover, inhibition of SHh signaling causes a reduction in Wnt-mediated transcriptional activity mediated by Gli3R, able to block the active form of the Wnt transcriptional effector, $\beta$-catenin, by physically interacting with the carboxy-terminal domain of $\beta$-catenin, a region that includes the transactivation domain (Ulloa et al., 2007).

Conversely, several data suggest an antagonism between $\mathrm{Hh}$ and WNT in CRC. In fact, a CRC cell line exposure to recombinant $\mathrm{SHh}$ results in the nuclear exit and membrane accumulation of $\beta$-catenin, consistent with its role in forming adherens junctions (Yoshimoto et al., 2012) and controlling epithelial-mesenchymal transition (EMT) (Varnat et al., 2010). In addition, it has been shown that Gli1/2 regulates the expression of secreted Frizzled-related protein sFRP-1 with a subsequent cytoplasmic accumulation of Wnt/ $\beta$-catenin (He et al., 2006). All these data agree with a clinical study that demonstrated the reverse association of Glil and $\beta$-catenin in human samples of CRC. This study also showed that the overexpression of exogenous Gli1 determines a reduction of nuclear $\beta$-catenin in CRC cell lines (Akiyoshi et al., 2006).

Moreover, it reported that IHh, required for normal colonic epithelial differentiation (Ramalho-Santos et al., 2000), is also able to antagonize the proliferative Wnt signaling in crypts by abrogating endogenous $\beta$-catenin/TCF signaling (van den Brink et al., 2004). Consistently, an analysis of patients with APC mutations showed the loss of IHh expression in dysplastic epithelial cells present in adenomas, suggesting that IHh expression is downregulated in response to constitutive $\beta$-catenin/TCF signaling ( $\mathrm{Fu}$ et al., 2014). In addition, Gli1 upregulates $\mathrm{SHh}$ expression, which is secreted from and acts on stromal cells, able to respond to SHh, enhancing Foxf1 and Foxf2 expression, which inhibit mesenchymal expression of Wnt5a and lead to suppression of $\beta$-catenin (Ormestad et al., 2006).

A controversial communication between $\mathrm{Hh}$ and Wnt signaling is highlighted in MB. In fact, on one hand, it is reported that $\mathrm{SuFu}$ is able to bind $\beta$-catenin and to export it from the nucleus and thereby to repress $\beta$-catenin/TCF-mediated transcription. Loss of SuFu function not only is associated with an increased risk of $\mathrm{MB}$ but also results in over-activity of both SHh and Wnt signaling pathways (Taylor et al., 2004). On the other hand, the activation of $\mathrm{Wnt} / \beta$-catenin signaling specifically decreases the proliferation of SHh-dependent cerebellar granule cell precursors (GCPs) (Poschl et al., 2014) and of SHh-MB cells, by inducing Gli to proteosomal degradation upon a direct interaction between $\beta$-catenin and Gli proteins (Zinke et al., 2015).

Of interest is the demonstration that the mutations in Wnt signaling are recently described in about $15 \%$ of $\mathrm{MB}$, corresponding to a minority, and defining a subset of patients with improved outcomes (Swartling et al., 2010). Nevertheless, N-Myc, a known target gene of the Wnt pathway, is also related to a subtype group of MB (Kool et al., 2008), suggesting its important role in the MB pathogenesis. Moreover, several groups report that $\mathrm{SHh}$ promotes the expression and post-transcriptional stabilization of N-Myc in mice (Kenney et al., 2003, Thomas et al., 2009).

To date, loss-of-function and gain-of-function mutations in known regulators of the Hh signaling pathway have been elucidated in hematological malignancies (Campbell and Copland, 2015), and the involvement of an autocrine and/or paracrine Hh signaling has been also demonstrated in multiple myeloma (Blotta et al., 2012), lymphoma (Dierks et al., 2007), and colon cancers (Bian et al., 2007; Yoshikawa et al., 2009). Genetic and epigenetic mutations in Wnt signaling components are also identified in leukemia (Staal et al., 2016). Intriguingly, the ability of $\mathrm{Hh}$ to crosstalk with Wnt is suggested by 
Sengupta and coworkers, who demonstrated that Hh signaling via Stat 3 activation gives rise to the expression of Wnt3a, Lef1, Gli1-3, and other target genes in the chronic phase of chronic myeloid leukemia (CML) (Sengupta et al., 2007). Although it has been reported that the $\mathrm{Hh}$ inhibitor cyclopamine and the WNT inhibitor quercitin suppress the growth of leukemia cells (Kawahara et al., 2009), direct crosstalk between Hedgehog and $\mathrm{Wnt} / \beta$-catenin in hematological disorders has not yet been well evaluated (Figure 2).

\section{Crosstalk Between Hh and TGF- $\beta$ Signaling Pathways}

Mammalian TGF- $\beta$ family members include more than 35 structurally related secreted proteins, including TGF- $\beta$ s stricto sensu, bone morphogenetic proteins (BMPs), growth differentiation factors (GDFs), glial-derived neurotrophic factors (GDNFs), Nodal, Lefty, and the Müllerian inhibitory substance/antiMüllerian hormone (MIS/AMH) (Zi et al., 2012). Members of the TGF- $\beta$ family play fundamental roles during embryonic development and in maintenance of tissue homeostasis since they regulate diverse cellular processes, such as proliferation, differentiation, migration, and extracellular matrix synthesis (Verrecchia and Mauviel, 2007).

Family members of TGF- $\beta$ stricto sensu are identified in three isoforms: TGF- $\beta 1$, TGF- $\beta 2$, and TGF- $\beta 3$. They signal via cellsurface receptors, which consist of specific hetero-oligomeric complex of type-I and type-II serine/threonine kinase receptors (TbR-I and TbR-II). Typically, TGF- $\beta$ signaling initiates with the binding to and subsequently activation of TbR-I and TbR-II. Smad proteins are the initial responders and transduce the signal from the TGF- $\beta$ receptor activation process. Smads comprise a family of structurally similar proteins with different functions: receptor-regulated (R-Smads), common mediator (Co-Smads), and inhibitory (I-Smads). After ligand binding, the TbR-II receptor phosphorylates TbR-I, which in turn phosphorylates and activates R-Smads (e.g., Smad2 and Smad3). Then, the R-Smads bind to Co-Smads (e.g., Smad4), and this complex translocates to the nucleus, where it regulates the transcription of TGF- $\beta$ responsive genes, involved in cytostatic and/or apoptotic events (p15 and p21) (Pardali et al., 2000; Seoane et al., 2001; Siegel and Massague, 2003), proliferation (c-Myc) (Chen et al., 2002), and the transcription of elements of other signaling pathways, such as Hes1 and Jagged1 (Zavadil et al., 2004). On the contrary, the I-Smads exert a negative feedback effect by competing with R-Smads for interaction with the receptor. Therefore, the I-Smads (e.g., Smad7) associate with ligand-TbR-I receptor complex and interfere with phosphorylation of R-Smads (e.g., Smad3), by preventing their interaction with activated TbR-I. Since the expression of Smad7 is induced by TGF- $\beta 1$, in turn, it inhibits TGF- $\beta$ signaling by a negative feedback system (Wahl, 1994, Moustakas et al., 2001). Several publications display a crosstalk between TGF- $\beta$ and Hh signaling pathways in cancer (Figure 2). In the onset of BCC, GLI2 is identified as an early target gene of the TGF- $\beta /$ SMAD cascade, independently by Hedgehog signaling activity (Dennler et al., 2007). Interestingly, Gli1 is induced by TGF- $\beta$ in a Gli2-dependent manner, and such an induction is not inhibited by cyclopamine, an SMO antagonist, demonstrating that $\mathrm{Hh}$ signaling is not required (Dennler et al., 2007). Concomitantly, studies show that TGF- $\beta$ inhibits PKA activity, which may contribute to increasing the pool of Gli activator proteins (Pierrat et al., 2012). In addition, Hh signaling induced the expression of TGF- $\beta$ members. In detail, in the mouse model of SMO-mediated BCC, Fan and colleagues identify TGF- $\beta 2$ as an Hh target gene (Fan et al., 2010). Thus, the crosstalk between Hh and TGF- $\beta$ may activate a vicious circuitry, able to promote and amplify downstream targets of Gli1/2, which in turn sustains the activation of TGF- $\beta$ and Hh itself (Figure 2).

During the development of the cerebellum, the GCPs express BMPs. It is reported that in GCPs, BMP-2 and -4 antagonize the proliferative effects of Hh through SMAD5. In addition, BMPs downregulate $\mathrm{Hh}$ signaling proteins such as SMO and Gli1. Moreover, it is suggested that BMP-2 inhibits proliferation and promotes cell differentiation of GCPs, by downregulating the oncogene N-Myc (Alvarez-Rodriguez et al., 2007).

It is well described that the architectural structure of the colon is controlled by a gradient of WNT, Hh, BMP, and Notch signaling (Geissler and Zach, 2012). In particular, BMP signaling exerts its function in the differentiated compartment at the top of the crypt, while it is relatively inactive in early compartments at the bottom of the crypt, due to the presence of the BMP inhibitor, Noggin (Syed, 2016). Thus, the Hh and BMP overlapping signaling pathways in the crypt regulate stem cell self-renewal, proliferation, and differentiation, but the existence of a direct regulation between them is not defined yet. However, loss of phosphorylation of Smad1, Smad5, and Smad8 is observed in $70 \%$ of sporadic colon cancer (Kodach et al., 2008). Loss of Smad4 or BMPRII function is the likely mechanistic basis for inactivated BMP signaling in sporadic colon cancer. In fact, several reports support the hypothesis that TGF- $\beta / B M P$ signaling is involved in invasion/metastasis events in tumor cells (Zavadil and Bottinger, 2005).

Although TGF- $\beta$ is proposed to be a potent negative regulator of hematopoiesis (Fortunel et al., 2000; Fortunel et al., 2003) and the loss of TGF- $\beta$ signaling is reported in several leukemias (Le Bousse-Kerdiles et al., 1996; DeCoteau et al., 1997; Jakubowiak et al., 2000; Imai et al., 2001; Wolfraim et al., 2004), the disruption of TGF- $\beta$ signaling alone is not sufficient to induce leukemia (Datto et al., 1999, Yang et al., 1999; Larsson et al., 2003). Thus, its role in leukemogenesis and its ability to crosstalk with other signaling pathways remain largely unknown.

\section{CONCLUSION}

Biological processes such as stem cell self-renewal, cell growth, and differentiation are orchestrated by a number of major signaling pathways that integrate with each other to modulate cell outcomes in response to several intracellular signals.

The picture in Figure 2 schematically summarizes the intricate molecular crosstalk between Hh, Notch, Wnt, and TGF- $\beta$, 
TABLE 1 | Mutations of $\mathrm{HH}$ signaling

\begin{tabular}{|c|c|c|c|c|c|c|}
\hline & Gene & Locus & Disease & Inheritance & Mutations & Reference \\
\hline \multirow[t]{21}{*}{ Loss of function } & \multirow{7}{*}{ Ptch1 } & \multirow{7}{*}{$9 q 22.32$} & Gorlin syndrome & Germline & Insertion deletion & Hahn et al., 1996; Lindstrom et al., 2006 \\
\hline & & & Rhabdomyosarcoma & Germline & Missense & $\begin{array}{l}\text { Bridge et al., 2000; } \\
\text { Taeubner et al., } 2018\end{array}$ \\
\hline & & & Medulloblastoma & Germline Somatic & $\begin{array}{l}\text { Insertion Deletion } \\
\text { Frameshift LOH }\end{array}$ & $\begin{array}{l}\text { Raffel et al., 1997; Reifenberger et al., } \\
\text { 1998; Zurawel et al., 2000; Thompson } \\
\text { et al., 2006; Kool et al., 2014; Rusert } \\
\text { et al., } 2014\end{array}$ \\
\hline & & & Basal cell carcinoma & Somatic & Missense LOH & $\begin{array}{l}\text { Gailani et al., 1996; } \\
\text { Reifenberger et al., } 2005\end{array}$ \\
\hline & & & Leukemia & Germline Somatic & Missense & Dagklis et al., 2015; Burns et al., 2018 \\
\hline & & & Breast cancer & NA & $\mathrm{LOH}$ & $\begin{array}{l}\text { Naylor et al., 2005; Wood et al., 2007; } \\
\text { Sinha et al., } 2008\end{array}$ \\
\hline & & & $\begin{array}{l}\text { Gastric-intestinal } \\
\text { cancer }\end{array}$ & NA & Frameshift Missense & Wang et al., 2013 \\
\hline & \multirow{4}{*}{ Ptch2 } & \multirow{4}{*}{$1 \mathrm{p} 34.1$} & Gorlin syndrome & Germline & Missense Frameshift & Fan and Eberhart, 2008; Fujii et al., 2013 \\
\hline & & & Rhabdomyosarcoma & Germline & Missense & Taeubner et al., 2018 \\
\hline & & & Leukemia & NA & Transition & Dagklis et al., 2015 \\
\hline & & & Gorlin syndrome & Germline & $\begin{array}{l}\text { Nonsense Missense } \\
\text { deletion }\end{array}$ & Smith et al., 2014 \\
\hline & \multirow{6}{*}{ SuFu } & \multirow{6}{*}{$10 q 24.32$} & Rhabdomyosarcoma & Germline & $\mathrm{LOH}$ & Bridge et al., 2000 \\
\hline & & & Medulloblastoma & Germline Somatic & Missense deletion & Taylor et al., 2002; Thompson et al., \\
\hline & & & & & Truncating $\mathrm{LOH}$ & $\begin{array}{l}\text { 2006; Rusert et al., 2014; Kool et al., } \\
2014\end{array}$ \\
\hline & & & Leukemia & Somatic & Missense & Burns et al., 2018 \\
\hline & & & Basal cell carcinoma & Somatic & Missense & Reifenberger et al., 2005 \\
\hline & & & Prostate cancer & Somatic & $\begin{array}{l}\mathrm{LOH} \text { deletion } \\
\text { Nonsense }\end{array}$ & Sheng et al., 2004 \\
\hline & \multirow{4}{*}{ Gli3 } & \multirow{4}{*}{$7 p 14.1$} & Meningioma & Germline & Missense LOH & Aavikko et al., 2012 \\
\hline & & & Pancreatic cancer & Somatic & Missense & Jones et al., 2008 \\
\hline & & & Leukemia & Germline Somatic & Missense & Dagklis et al., 2015; Burns et al., 2018 \\
\hline & & & Colorectal cancer & NA & Missense & Wood et al., 2007 \\
\hline \multirow[t]{15}{*}{ Gain of function } & \multirow{6}{*}{ Gli1 } & \multirow{6}{*}{$12 q 13.3$} & Rhabdomyosarcoma & Germline & Amplification & Roberts et al., 1989 \\
\hline & & & Medulloblastoma & Somatic & Amplification & $\begin{array}{l}\text { Thompson et al., 2006; Northcott et al., } \\
2009\end{array}$ \\
\hline & & & Leukemia & Somatic & Missense & Dagklis et al., 2015; Burns et al., 2018 \\
\hline & & & Breast cancer & Somatic & Amplification & $\begin{array}{l}\text { Nessling et al., 2005; Wood et al., 2007; } \\
\text { Jiao et al., } 2012\end{array}$ \\
\hline & & & Pancreatic cancer & Somatic & Missense & Jones et al., 2008 \\
\hline & & & Colorectal cancer & Somatic & Frameshift & Lee et al., 2018 \\
\hline & \multirow[t]{3}{*}{ Gli2 } & \multirow[t]{3}{*}{$2 q 14.2$} & Medulloblastoma & Somatic & Amplification & $\begin{array}{l}\text { Northcott et al., 2009; Rusert et al., 2014; } \\
\text { Kool et al., } 2014\end{array}$ \\
\hline & & & Leukemia & Somatic & Missense & Burns et al., 2018; \\
\hline & & & Medulloblastoma & Somatic & Missense & $\begin{array}{l}\text { Reifenberger et al., 1998; Rusert et al., } \\
\text { 2014; Kool et al., } 2014\end{array}$ \\
\hline & \multirow{3}{*}{$\mathrm{SMO}$} & \multirow{3}{*}{$7 q 32.1$} & Basal cell carcinoma & Somatic & Missense & $\begin{array}{l}\text { Reifenberger et al., 1998; Reifenberger } \\
\text { et al., } 2005\end{array}$ \\
\hline & & & Leukemia & Somatic & Frameshift & Dagklis et al., 2015 \\
\hline & & & $\begin{array}{l}\text { Gastric-intestinal } \\
\text { cancer }\end{array}$ & NA & Missense Insertion & Wang et al., 2013 \\
\hline & \multirow{3}{*}{$\mathrm{SHH}$} & \multirow{3}{*}{$7 q 36.3$} & Ameloblastoma & Somatic & Missense & Sweeney et al., 2014 \\
\hline & & & Medulloblastoma & NA & Amplification & Reifenberger et al., 1998; Kool et al., 2014 \\
\hline & & & Basal cell carcinoma & Somatic & Missense & Couve-Privat et al., 2004 \\
\hline
\end{tabular}

which establishes a network of protein-protein interactions able to affect gene expression programs across the pathways. The cartoon clearly represents the complexity of molecular interlinking inside the tumor cell, which is underlying the severity of the neoplasia phenomenon. The pathogenesis of malignancies is characterized by dysregulation of at least two pathways at the same time, proving a functional advantage to neoplastic cells, influencing relapse and drug responsiveness.
We need to unravel the intricate signaling networks between the major pathways to prevent tumor formation and/or to contribute to the development of novel anticancer treatment modalities. Aberrant activation of the Hh pathway is tightly associated with cancer development. Notably, a plethora of stimuli activate multiple signaling cascades in tumor cells, which can impinge on $\mathrm{Hh}$ signaling and affect its output, by direct protein-protein interaction or by regulating indirectly the expression of key 
components of the signaling. Conversely, the Hh pathway can also have an impact on other pathways, determining a mutual signaling interference, a phenomenon underlying an unbalanced network in cancer cells. The Hh signaling pathway is considered an important molecular cross point able to integrate/synergize with other major signaling cascades, such as Wnt, TGF- $\beta$, and Notch. Therefore, Figure 2 presents an overview concerning direct or indirect molecular mechanisms that sustain $\mathrm{Hh}$ cross-talking with major signaling pathways. Molecular sharing between $\mathrm{Hh}$ and the Wnt/ $\beta$-catenin, Notch, or TGF- $\beta$ signaling pathway suggests that two major signaling networks crosstalk with each other during oncogenesis. Therefore, a combined involvement of these signaling pathways in early stages of tumorigenesis as well as in the metastatic process in several types of cancers suggests the need to combine novel targeted inhibitors with standard antineoplastic therapy to enhance therapy efficacy.

This complex scenario could open a huge window of opportunity for the development of new therapeutic drugs for multiple cancers.

\section{REFERENCES}

Aavikko, M., Li, S. P., Saarinen, S., Alhopuro, P., Kaasinen, E., Morgunova, E., et al. (2012). Loss of SUFU function in familial multiple meningioma. Am. J. Hum. Genet. 91, 520-526. doi: 10.1016/j.ajhg.2012.07.015

Aberger, F., Hutterer, E., Sternberg, C., Del Burgo, P. J., and Hartmann, T. N. (2017). Acute myeloid leukemia-strategies and challenges for targeting oncogenic Hedgehog/ GLI signaling. Cell Commun. Signal 15, 8. doi: 10.1186/s12964-017-0163-4

Akiyoshi, T., Nakamura, M., Koga, K., Nakashima, H., Yao, T., Tsuneyoshi, M., et al. (2006). Glil, downregulated in colorectal cancers, inhibits proliferation of colon cancer cells involving Wnt signalling activation. Gut 55, 991-999. doi: 10.1136/gut.2005.080333

Allman, D., Karnell, F. G., Punt, J. A., Bakkour, S., Xu, L., Myung, P., et al. (2001). Separation of Notch1 promoted lineage commitment and expansion/ transformation in developing T cells. J. Exp. Med. 194, 99-106. doi: 10.1084/ jem.194.1.99

Alvarez-Rodriguez, R., Barzi, M., Berenguer, J., and Pons, S. (2007). Bone morphogenetic protein 2 opposes Shh-mediated proliferation in cerebellar granule cells through a TIEG-1-based regulation of Nmyc. J. Biol. Chem. 282, 37170-37180. doi: 10.1074/jbc.M705414200

Androutsellis-Theotokis, A., Leker, R. R., Soldner, F., Hoeppner, D. J., Ravin, R., Poser, S. W., et al. (2006). Notch signalling regulates stem cell numbers in vitro and in vivo. Nature 442, 823-826. doi: 10.1038/nature04940

Arruga, F., Gizdic, B., Serra, S., Vaisitti, T., Ciardullo, C., Coscia, M., et al. (2014). Functional impact of NOTCH1 mutations in chronic lymphocytic leukemia. Leukemia 28, 1060-1070. doi: 10.1038/leu.2013.319

Bai, C. B., Stephen, D., and Joyner, A. L. (2004). All mouse ventral spinal cord patterning by hedgehog is Gli dependent and involves an activator function of Gli3. Dev. Cell 6, 103-115. doi: 10.1016/S1534-5807(03)00394-0

Bakshi, A., Chaudhary, S. C., Rana, M., Elmets, C. A., and Athar, M. (2017). Basal cell carcinoma pathogenesis and therapy involving hedgehog signaling and beyond. Mol. Carcinog. 56, 2543-2557. doi: 10.1002/mc.22690

Bellavia, D., Campese, A. F., Alesse, E., Vacca, A., Felli, M. P., Balestri, A., et al. (2000). Constitutive activation of NF-kappaB and T-cell leukemia/lymphoma in Notch3 transgenic mice. EMBO J. 19, 3337-3348. doi: 10.1093/emboj/19.13.3337

Bellavia, D., Mecarozzi, M., Campese, A. F., Grazioli, P., Gulino, A., and Screpanti, I. (2007a). Notch and Ikaros: not only converging players in T cell leukemia. Cell Cycle 6, 2730-2734. doi: 10.4161/cc.6.22.4894

Bellavia, D., Mecarozzi, M., Campese, A. F., Grazioli, P., Talora, C., Frati, L., et al., (2007b). Notch3 and the Notch3-upregulated RNA-binding protein HuD

\section{AUTHOR CONTRIBUTIONS}

MP, SZ, and DB wrote the paper. MP, SZ, and FN prepared the figures. SC, IS, and DB reviewed drafts of the paper. All authors read and approved the final manuscript.

\section{FUNDING}

This work was supported by the following grants: Sapienza University (Progetti H2020 collaborativi) \#PH118164340087CF (to IS) and Sapienza University 2016 project \#RP116154CE3DD739 (to DB).

\section{ACKNOWLEDGMENTS}

This work is dedicated to the memory of Alberto Gulino, an outstanding scientist and mentor.

This work has been supported by the Italian Ministry of Education, University and Research-Dipartimenti di Eccellenza, L. $232 / 2016$.

regulate Ikaros alternative splicing. EMBO J. 26, 1670-1680. doi: 10.1038/ sj.emboj.7601626

Bellavia, D., Palermo, R., Felli, M. P., Screpanti, I., and Checquolo, S. (2018). Notch signaling as a therapeutic target for acute lymphoblastic leukemia. Expert Opin. Ther. Targets 22, 331-342. doi: 10.1080/14728222.2018.1451840

Beverly, L. J., and Capobianco, A. J. (2003). Perturbation of Ikaros isoform selection by MLV integration is a cooperative event in Notch(IC)-induced T cell leukemogenesis. Cancer cell 3, 551-564. doi: 10.1016/S1535-6108(03)00137-5

Bian, Y. H., Huang, S. H., Yang, L., Ma, X. L., Xie, J. W., and Zhang, H. W. (2007). Sonic hedgehog-Glil pathway in colorectal adenocarcinomas. World J. Gastroenterol. 13, 1659-1665. doi: 10.3748/wjg.v13.i11.1659

Bigelow, R. L., Chari, N. S., Unden, A. B., Spurgers, K. B., Lee, S., Roop, D. R., et al. (2004). Transcriptional regulation of bcl-2 mediated by the sonic hedgehog signaling pathway through gli-1. J. Biol. Chem. 279, 1197-1205. doi: 10.1074/ jbc.M310589200

Blotta, S., Jakubikova, J., Calimeri, T., Roccaro, A. M., Amodio, N., Azab, A. K., et al. (2012). Canonical and noncanonical Hedgehog pathway in the pathogenesis of multiple myeloma. Blood 120, 5002-5013. doi: 10.1182/blood-2011-07-368142

Bonifas, J. M., Pennypacker, S., Chuang, P. T., McMahon, A. P., Williams, M., Rosenthal, A., et al. (2001). Activation of expression of hedgehog target genes in basal cell carcinomas. J. Investig. Dermatol. 116, 739-742. doi: 10.1046/ j.1523-1747.2001.01315.x

Brannon, M., Gomperts, M., Sumoy, L., Moon, R. T., and Kimelman, D. (1997). A beta-catenin/XTcf-3 complex binds to the siamois promoter to regulate dorsal axis specification in Xenopus. Genes Dev. 11, 2359-2370. doi: 10.1101/gad.11.18.2359

Bridge, J. A., Liu, J., Weibolt, V., Baker, K. S., Perry, D., Kruger, R., et al. (2000). Novel genomic imbalances in embryonal rhabdomyosarcoma revealed by comparative genomic hybridization and fluorescence in situ hybridization: an intergroup rhabdomyosarcoma study. Genes Chromosomes Cancer 27, 337344. doi: 10.1002/(SICI)1098-2264(200004)27:4<337::AID-GCC1>3.0.CO;2-1

Burns, M. A., Liao, Z. W., Yamagata, N., Pouliot, G. P., Stevenson, K. E., Neuberg, D. S., et al. (2018). Hedgehog pathway mutations drive oncogenic transformation in high-risk T-cell acute lymphoblastic leukemia. Leukemia 32, 2126-2137. doi: 10.1038/s41375-018-0097-x

Campbell, V., and Copland, M. (2015). Hedgehog signaling in cancer stem cells: a focus on hematological cancers. Stem Cells Cloning 8, 27-38. doi: 10.2147/ SCCAA.S58613

Campese, A. F., Bellavia, D., Gulino, A., and Screpanti, I. (2003). Notch signalling at the crossroads of T cell development and leukemogenesis. Semin. Cell Dev. Biol. 14, 151-157. doi: 10.1016/S1084-9521(02)00184-2 
Campese, A. F., Grazioli, P., Colantoni, S., Anastasi, E., Mecarozzi, M., Checquolo, S., et al. (2009). Notch3 and pTalpha/pre-TCR sustain the in vivo function of naturally occurring regulatory T cells. Int. Immunol. 21, 727-743. doi: 10.1093/intimm/ dxp042

Canettieri, G., Di Marcotullio, L., Greco, A., Coni, S., Antonucci, L., Infante, P., et al. (2010). Histone deacetylase and Cullin3-REN(KCTD11) ubiquitin ligase interplay regulates Hedgehog signalling through Gli acetylation. Nat. Cell Biol. 12, 132-142. doi: 10.1038/ncb2013

Carballo, G. B., Honorato, J. R., de Lopes, G. P. F., and Spohr, T. (2018). A highlight on Sonic hedgehog pathway. Cell Commun. Signal 16, 11. doi: 10.1186/s12964018-0220-7

Catanzaro, G., Sabato, C., Russo, M., Rosa, A., Abballe, L., Besharat, Z. M., et al. (2017). Loss of miR-107, miR-181c and miR-29a-3p promote activation of Notch2 signaling in pediatric high-grade gliomas (pHGGs). Int. J. Mol. Sci. 18, 2742-2754. doi: 10.3390/ijms18122742

Cavallo, R. A., Cox, R. T., Moline, M. M., Roose, J., Polevoy, G. A., Clevers, H., et al. (1998). Drosophila Tcf and Groucho interact to repress Wingless signalling activity. Nature 395, 604-608. doi: 10.1038/26982

Ceccarelli, S., Megiorni, F., Bellavia, D., Marchese, C., Screpanti, I., and Checquolo, S. (2019). Notch3 targeting: a novel weapon against ovarian cancer stem cells. Stem Cells Int. 2019, 6264931. doi: 10.1155/2019/6264931

Checquolo, S., Palermo, R., Cialfi, S., Ferrara, G., Oliviero, C., Talora, C., et al. (2010). Differential subcellular localization regulates c-Cbl E3 ligase activity upon Notch3 protein in T-cell leukemia. Oncogene 29, 1463-1474. doi: 10.1038/onc.2009.446

Chen, C. R., Kang, Y., Siegel, P. M., and Massague, J. (2002). E2F4/5 and p107 as Smad cofactors linking the TGFbeta receptor to c-myc repression. Cell 110, 19-32. doi: 10.1016/S0092-8674(02)00801-2

Chen, Y., Sasai, N., Ma, G., Yue, T., Jia, J., Briscoe, J., et al. (2011). Sonic Hedgehog dependent phosphorylation by CK1alpha and GRK2 is required for ciliary accumulation and activation of smoothened. PLoS Biol. 9, e1001083. doi: 10.1371/journal.pbio. 1001083

Choi, J. H., Park, J. T., Davidson, B., Morin, P. J., Shih Ie, M., and Wang, T. L. (2008). Jagged-1 and Notch3 juxtacrine loop regulates ovarian tumor growth and adhesion. Cancer Res. 68, 5716-5723. doi: 10.1158/0008-5472.CAN-08-0001

Cialfi, S., Palermo, R., Manca, S., Checquolo, S., Bellavia, D., Pelullo, M., et al. (2013). Glucocorticoid sensitivity of T-cell lymphoblastic leukemia/lymphoma is associated with glucocorticoid receptor-mediated inhibition of Notch1 expression. Leukemia 27, 485-488. doi: 10.1038/leu.2012.192

Cialfi, S., Palermo, R., Manca, S., De Blasio, C., Vargas Romero, P., Checquolo, S., et al. (2014). Loss of Notch1-dependent p21(Waf1/Cip1) expression influences the Notch1 outcome in tumorigenesis. Cell cycle 13, 2046-2055. doi: 10.4161/ cc. 29079

Clevers, H. (2006). Wnt/beta-catenin signaling in development and disease. Cell 127, 469-480. doi: 10.1016/j.cell.2006.10.018

Cohen, B., Shimizu, M., Izrailit, J., Ng, N. F., Buchman, Y., Pan, J. G., et al. (2010). Cyclin D1 is a direct target of JAG1-mediated Notch signaling in breast cancer. Breast Cancer Res. Treat. 123, 113-124. doi: 10.1007/s10549-009-0621-9

Coni, S., Antonucci, L., D'Amico, D., Di Magno, L., Infante, P., De Smaele, E., et al. (2013). Gli2 acetylation at lysine 757 regulates hedgehog-dependent transcriptional output by preventing its promoter occupancy. PloS One 8, e65718. doi: 10.1371/journal.pone.0065718

Couve-Privat, S., Le Bret, M., Traiffort, E., Queille, S., Coulombe, J., Bouadjar, B., et al. (2004). Functional analysis of novel sonic hedgehog gene mutations identified in basal cell carcinomas from xeroderma pigmentosum patients. Cancer Res. 64, 3559-3565. doi: 10.1158/0008-5472.CAN-03-4040

Crompton, T., Outram, S. V., and Hager-Theodorides, A. L. (2007). Sonic hedgehog signalling in T-cell development and activation. Nat. Rev. Immunol. 7, 726-735. doi: $10.1038 /$ nri2151

Dagklis, A., Demeyer, S., De Bie, J., Radaelli, E., Pauwels, D., Degryse, S., et al. (2016). Hedgehog pathway activation in T-cell acute lymphoblastic leukemia predicts response to SMO and GLI1 inhibitors. Blood 128, 2642-2654. doi: 10.1182/blood-2016-03-703454

Dagklis, A., Pauwels, D., Lahortiga, I., Geerdens, E., Bittoun, E., Cauwelier, B., et al. (2015). Hedgehog pathway mutations in T-cell acute lymphoblastic leukemia. Haematologica 100, e102-e105. doi: 10.3324/haematol.2014.119248

Dai, P., Akimaru, H., Tanaka, Y., Maekawa, T., Nakafuku, M., and Ishii, S. (1999). Sonic Hedgehog-induced activation of the Gli1 promoter is mediated by GLI3. J. Biol. Chem. 274, 8143-8152. doi: 10.1074/jbc.274.12.8143
Datto, M. B., Frederick, J. P., Pan, L., Borton, A. J., Zhuang, Y., and Wang, X. F. (1999). Targeted disruption of Smad3 reveals an essential role in transforming growth factor beta-mediated signal transduction. Mol. Cell. Biol. 19, 24952504. doi: 10.1128/MCB.19.4.2495

De Falco, F., Del Papa, B., Baldoni, S., Sabatini, R., Falzetti, F., Di Ianni, M., et al. (2018). IL-4-dependent Jagged1 expression/processing is associated with survival of chronic lymphocytic leukemia cells but not with Notch activation. Cell Death Dis 9, 1160. doi: 10.1038/s41419-018-1185-6

De Falco, F., Sabatini, R., Falzetti, F., Di Ianni, M., Sportoletti, P., Baldoni, S., et al. (2015). Constitutive phosphorylation of the active Notch1 intracellular domain in chronic lymphocytic leukemia cells with NOTCH1 mutation. Leukemia 29, 994-998. doi: 10.1038/leu.2014.329

Decker, S., Zirlik, K., Djebatchie, L., Hartmann, D., Ihorst, G., Schmitt-Graeff, A., et al. (2012). Trisomy 12 and elevated GLI1 and PTCH1 transcript levels are biomarkers for Hedgehog-inhibitor responsiveness in CLL. Blood 119, 9971007. doi: 10.1182/blood-2011-06-359075

DeCoteau, J. F., Knaus, P. I., Yankelev, H., Reis, M. D., Lowsky, R., Lodish, H. F., et al. (1997). Loss of functional cell surface transforming growth factor beta (TGF-beta) type 1 receptor correlates with insensitivity to TGF-beta in chronic lymphocytic leukemia. Proc. Natl Acad. Sci. U. S. A. 94, 5877-5881. doi: 10.1073/pnas.94.11.5877

Denef, N., Neubuser, D., Perez, L., and Cohen, S. M. (2000). Hedgehog induces opposite changes in turnover and subcellular localization of patched and smoothened. Cell 102, 521-531. doi: 10.1016/S0092-8674(00)00056-8

Dennler, S., Andre, J., Alexaki, I., Li, A., Magnaldo, T., ten Dijke, P., et al. (2007). Induction of sonic hedgehog mediators by transforming growth factor-beta: Smad3-dependent activation of Gli2 and Gli1 expression in vitro and in vivo. Cancer Res. 67, 6981-6986. doi: 10.1158/0008-5472.CAN-07-0491

Di Marcotullio, L., Ferretti, E., Greco, A., De Smaele, E., Po, A., Sico, M. A., et al. (2006). Numb is a suppressor of Hedgehog signalling and targets Gli1 for itchdependent ubiquitination. Nat. Cell Biol. 8, 1415-1423. doi: 10.1038/ncb1510

Di Marcotullio, L., Ferretti, E., Greco, A., De Smaele, E., Screpanti, I., and Gulino, A. (2007). Multiple ubiquitin-dependent processing pathways regulate hedgehog/ gli signaling: implications for cell development and tumorigenesis. Cell Cycle 6, 390-393. doi: 10.4161/cc.6.4.3809

Di Marcotullio, L., Greco, A., Mazza, D., Canettieri, G., Pietrosanti, L., Infante, P., et al. (2011). Numb activates the E3 ligase Itch to control Glil function through a novel degradation signal. Oncogene 30, 65-76. doi: 10.1038/onc.2010.394

Dierks, C., Grbic, J., Zirlik, K., Beigi, R., Englund, N. P., Guo, G. R., et al. (2007). Essential role of stromally induced hedgehog signaling in B-cell malignancies. Nat. Med. 13, 944-951. doi: 10.1038/nm1614

Diluvio, G., Del Gaudio, F., Giuli, M. V., Franciosa, G., Giuliani, E., Palermo, R., et al. (2018). NOTCH3 inactivation increases triple negative breast cancer sensitivity to gefitinib by promoting EGFR tyrosine dephosphorylation and its intracellular arrest. Oncogenesis 7, 42. doi: 10.1038/s41389-018-0051-9

Ding, Q., Fukami, Si, Meng, X., Nishizaki, Y., Zhang, X., Sasaki, H., et al. (1999). Mouse suppressor of fused is a negative regulator of sonic hedgehog signaling and alters the subcellular distribution of Gli1. Curr. Biol. 9, 1119-1122. doi: 10.1016/S0960-9822(99)80482-5

Domingo-Domenech, J., Vidal, S. J., Rodriguez-Bravo, V., Castillo-Martin, M., Quinn, S. A., Rodriguez-Barrueco, R., et al. (2012). Suppression of acquired docetaxel resistance in prostate cancer through depletion of notch- and hedgehog-dependent tumor-initiating cells. Cancer Cell 22, 373-388. doi: 10.1016/j.ccr.2012.07.016

Drakopoulou, E., Outram, S. V., Rowbotham, N. J., Ross, S. E., Furmanski, A. L., Saldana, J. I., et al. (2010). Non-redundant role for the transcription factor Gli1 at multiple stages of thymocyte development. Cell Cycle 9, 4144-4152. doi: $10.4161 /$ cc. 9.20 .13453

Dunaeva, M., Michelson, P., Kogerman, P., and Toftgard, R. (2003). Characterization of the physical interaction of Gli proteins with SUFU proteins. J. Biol. Chem. 278, 5116-5122. doi: 10.1074/jbc.M209492200

Ezratty, E. J., Stokes, N., Chai, S., Shah, A. S., Williams, S. E., and Fuchs, E. (2011). A role for the primary cilium in Notch signaling and epidermal differentiation during skin development. Cell 145, 1129-1141. doi: 10.1016/j. cell.2011.05.030

Fan, Q., He, M., Sheng, T., Zhang, X., Sinha, M., Luxon, B., et al. (2010). Requirement of TGFbeta signaling for SMO-mediated carcinogenesis. J. Biol. Chem. 285, 36570-36576. doi: 10.1074/jbc.C110.164442 
Fan, X., Mikolaenko, I., Elhassan, I., Ni, X., Wang, Y., Ball, D., et al. (2004). Notch1 and notch2 have opposite effects on embryonal brain tumor growth. Cancer Res. 64, 7787-7793. doi: 10.1158/0008-5472.CAN-04-1446

Fan, X., and Eberhart, C. G. (2008). Medulloblastoma stem cells. J. Clin. Oncol. 26 (17), 2821-2827. doi: 10.1200/JCO.2007.15.2264

Felli, M. P., Maroder, M., Mitsiadis, T. A., Campese, A. F., Bellavia, D., Vacca, A., et al. (1999). Expression pattern of Notch1, 2 and 3 and Jagged 1 and 2 in lymphoid and stromal thymus components: distinct ligand-receptor interactions in intrathymic T cell development. Int. Immunol. 11, 1017-1025. doi: 10.1093/ intimm/11.7.1017

Ferrandino, F., Bernardini, G., Tsaouli, G., Grazioli, P., Campese, A. F., Noce, C., et al. (2018a). Intrathymic Notch3 and CXCR4 combinatorial interplay facilitates T-cell leukemia propagation. Oncogene 37, 6285-6298. doi: 10.1038/s41388-0180401-2

Ferrandino, F., Grazioli, P., Bellavia, D., Campese, A. F., Screpanti, I., and Felli, M. P. (2018b). Notch and NF-kappaB: coach and players of regulatory T-cell response in cancer. Front. Immunol. 9, 2165. doi: 10.3389/fimmu.2018.02165

Fortini, M. E. (2009). Notch signaling: the core pathway and its posttranslational regulation. Dev. Cell 16, 633-647. doi: 10.1016/j.devcel.2009.03.010

Fortunel, N. O., Hatzfeld, A., and Hatzfeld, J. A. (2000). Transforming growth factor-beta: pleiotropic role in the regulation of hematopoiesis. Blood 96, 2022-2036.

Fortunel, N. O., Hatzfeld, J. A., Monier, M. N., and Hatzfeld, A. (2003). Control of hematopoietic stem/progenitor cell fate by transforming growth factor-beta. Oncol. Res. 13, 445-453. doi: 10.3727/096504003108748483

Franciosa, G., Diluvio, G., Gaudio, F. D., Giuli, M. V., Palermo, R., Grazioli, P., et al. (2016). Prolyl-isomerase Pin 1 controls Notch3 protein expression and regulates T-ALL progression. Oncogene 35, 4741-4751. doi: 10.1038/onc.2016.5

Fu, X., Shi, L., Zhang, W., Zhang, X., Peng, Y., Chen, X., et al. (2014). Expression of Indian hedgehog is negatively correlated with APC gene mutation in colorectal tumors. Int. J. Clin. Exp. Med. 7, 2150-2155.

Fujii, K., Ohashi, H., Suzuki, M., Hatsuse, H., Shiohama, T., Uchikawa, H., et al. (2013). Frameshift mutation in the PTCH2 gene can cause nevoid basal cell carcinoma syndrome. Fam. Cancer 12, 611-614 doi: 10.1007/s10689-0139623-1

Gailani, M. R., Stahle-Backdahl, M., Leffell, D. J., Glynn, M., Zaphiropoulos, P. G., Pressman, C., et al. (1996). The role of the human homologue of Drosophila patched in sporadic basal cell carcinomas. Nat. Genet. 14, 78-81. doi: 10.1038/ ng0996-78

Gao, J., Graves, S., Koch, U., Liu, S., Jankovic, V., Buonamici, S., et al. (2009). Hedgehog signaling is dispensable for adult hematopoietic stem cell function. Cell Stem Cell 4, 548-558. doi: 10.1016/j.stem.2009.03.015

Geissler, K., and Zach, O. (2012). Pathways involved in Drosophila and human cancer development: the Notch, Hedgehog, Wingless, Runt, and Trithorax pathway. Ann. Hematol 91, 645-669. doi: 10.1007/s00277-012-1435-0

Goetz, S. C., and Anderson, K. V. (2010). The primary cilium: a signalling centre during vertebrate development. Nat. Rev. Genet. 11, 331-344. doi: 10.1038/ nrg2774

Guleng, B., Tateishi, K., Ohta, M., Asaoka, Y., Jazag, A., Lin, L. J., et al. (2006). Smoothened gene mutations found in digestive cancer have no aberrant Hedgehog signaling activity. J. Gastroenterol. 41, 1238-1239. doi: 10.1007/ s00535-006-1955-2

Guo, S., Liu, M., and Gonzalez-Perez, R. R. (2011). Role of Notch and its oncogenic signaling crosstalk in breast cancer. Biochim. Biophys. Acta 1815, 197-213. doi: 10.1016/j.bbcan.2010.12.002

Hahn, H., Wicking, C., Zaphiropoulous, P. G., Gailani, M. R., Shanley, S., Chidambaram, A., et al. (1996). Mutations of the human homolog of Drosophila patched in the nevoid basal cell carcinoma syndrome. Cell 85, 841-851. doi: 10.1016/S0092-8674(00)81268-4

Harris, P. J., Speranza, G., and Dansky Ullmann, C. (2012). Targeting embryonic signaling pathways in cancer therapy. Expert Opin. Ther. Targets 16, 131-145. doi: $10.1517 / 14728222.2011 .645808$

He, J., Sheng, T., Stelter, A. A., Li, C., Zhang, X., Sinha, M., et al. (2006). Suppressing Wnt signaling by the hedgehog pathway through sFRP-1. J. Biol. Chem. 281, 35598-35602. doi: 10.1074/jbc.C600200200

He, T. C., Sparks, A. B., Rago, C., Hermeking, H., Zawel, L., da Costa, L. T., et al. (1998). Identification of c-MYC as a target of the APC pathway. Science 281, 1509-1512. doi: 10.1126/science.281.5382.1509
He, X., Semenov, M., Tamai, K., and Zeng, X. (2004). LDL receptor-related proteins 5 and 6 in Wnt/beta-catenin signaling: arrows point the way. Development 131, 1663-1677. doi: 10.1242/dev.01117

Hou, X., Chen, X., Zhang, P., Fan, Y., Ma, A., Pang, T., et al. (2014). Inhibition of hedgehog signaling by GANT58 induces apoptosis and shows synergistic antitumor activity with AKT inhibitor in acute T cell leukemia cells. Biochimie 101, 50-59. doi: 10.1016/j.biochi.2013.12.019

Huang, P., Xiong, F., Megason, S. G., and Schier, A. F. (2012). Attenuation of Notch and Hedgehog signaling is required for fate specification in the spinal cord. PLoS Genet. 8, e1002762. doi: 10.1371/journal.pgen.1002762

Humke, E. W., Dorn, K. V., Milenkovic, L., Scott, M. P., and Rohatgi, R. (2010). The output of Hedgehog signaling is controlled by the dynamic association between Suppressor of Fused and the Gli proteins. Genes Dev. 24, 670-682. doi: 10.1101/ gad. 1902910

Huttner, A. (2012). Overview of primary brain tumors: pathologic classification, epidemiology, molecular biology, and prognostic markers. Hematol. Oncol. Clin. North Am. 26, 715-732. doi: 10.1016/j.hoc.2012.05.004

Imai, Y., Kurokawa, M., Izutsu, K., Hangaishi, A., Maki, K., Ogawa, S., et al. (2001). Mutations of the Smad4 gene in acute myelogenous leukemia and their functional implications in leukemogenesis. Oncogene 20, 88-96. doi: 10.1038/ sj.onc. 1204057

Infante, P., Alfonsi, R., Ingallina, C., Quaglio, D., Ghirga, F., D’Acquarica, I., et al. (2016). Inhibition of Hedgehog-dependent tumors and cancer stem cells by a newly identified naturally occurring chemotype. Cell Death Dis. 7, e2376. doi: 10.1038/cddis.2016.195

Infante, P., Faedda, R., Bernardi, F., Bufalieri, F., Lospinoso Severini, L., Alfonsi, R., et al. (2018). Itch/beta-arrestin2-dependent non-proteolytic ubiquitylation of SuFu controls Hedgehog signalling and medulloblastoma tumorigenesis. Nat. Commun. 9, 976. doi: 10.1038/s41467-018-03339-0

Ingram, W. J., McCue, K. I., Tran, T. H., Hallahan, A. R., and Wainwright, B. J. (2008). Sonic Hedgehog regulates Hesl through a novel mechanism that is independent of canonical Notch pathway signalling. Oncogene 27, 1489-1500. doi: 10.1038/sj.onc. 1210767

Jakubowiak, A., Pouponnot, C., Berguido, F., Frank, R., Mao, S., Massague, J., et al. (2000). Inhibition of the transforming growth factor beta 1 signaling pathway by the AML1/ETO leukemia-associated fusion protein. J. Biol. Chem. 275, 40282-40287. doi: 10.1074/jbc.C000485200

Ji, Z., Mei, F. C., Johnson, B. H., Thompson, E. B., and Cheng, X. (2007). Protein kinase A, not Epac, suppresses hedgehog activity and regulates glucocorticoid sensitivity in acute lymphoblastic leukemia cells. J. Biol. Chem. 282, 3737037377. doi: 10.1074/jbc.M703697200

Jiao, X., Wood, L. D., Lindman, M., Jones, S., Buckhaults, P., Polyak, K., et al. (2012). Somatic mutations in the Notch, NF-KB, PIK3CA, and Hedgehog pathways in human breast cancers. Genes Chromosomes Cancer 51, 480-489. doi: $10.1002 /$ gcc. 21935

Johnson, R. L., Rothman, A. L., Xie, J., Goodrich, L. V., Bare, J. W., Bonifas, J. M., et al. (1996). Human homolog of patched, a candidate gene for the basal cell nevus syndrome. Science 272, 1668-1671. doi: 10.1126/science.272.5268.1668

Jones, E. A., Sajid, M. I., Shenton, A., and Evans, D. G. (2011). Basal cell carcinomas in Gorlin syndrome: a review of 202 patients. J. Skin Cancer 2011, 217378. doi: $10.1155 / 2011 / 217378$

Jones, S., Zhang, X., Parsons, D. W., Lin, J. C., Leary, R. J., Angenendt, P., et al. (2008). Core signaling pathways in human pancreatic cancers revealed by global genomic analyses. Science 321, 1801-1806. doi: 10.1126/science.1164368

Joshi, I., Minter, L. M., Telfer, J., Demarest, R. M., Capobianco, A. J., Aster, J. C., et al. (2009). Notch signaling mediates G1/S cell-cycle progression in T cells via cyclin D3 and its dependent kinases. Blood 113, 1689-1698. doi: 10.1182/ blood-2008-03-147967

Joutel, A., Dodick, D. D., Parisi, J. E., Cecillon, M., Tournier-Lasserve, E., and Bousser, M. G. (2000). De novo mutation in the Notch3 gene causing CADASIL. Ann. Neurol 47, 388-391. doi: 10.1002/1531-8249(200003)47:3<388::AIDANA19>3.0.CO;2-Q

Katoh, Y., and Katoh, M. (2009). Hedgehog target genes: mechanisms of carcinogenesis induced by aberrant hedgehog signaling activation. Curr. Mol. Med. 9, 873-886. doi: 10.2174/156652409789105570

Kawahara, T., Kawaguchi-Ihara, N., Okuhashi, Y., Itoh, M., Nara, N., and Tohda, S. (2009). Cyclopamine and quercetin suppress the growth of leukemia and lymphoma cells. Anticancer Res. 29, 4629-4632. 
Kenney, A. M., Cole, M. D., and Rowitch, D. H. (2003). Nmyc upregulation by sonic hedgehog signaling promotes proliferation in developing cerebellar granule neuron precursors. Development 130, 15-28. doi: 10.1242/dev.00182

Kim, T. H., Kim, B. M., Mao, J., Rowan, S., and Shivdasani, R. A. (2011). Endodermal Hedgehog signals modulate Notch pathway activity in the developing digestive tract mesenchyme. Development 138, 3225-3233. doi: 10.1242/dev.066233

Kodach, L. L., Wiercinska, E., de Miranda, N. F., Bleuming, S. A., Musler, A. R., Peppelenbosch, M. P., et al. (2008). The bone morphogenetic protein pathway is inactivated in the majority of sporadic colorectal cancers. Gastroenterology 134, 1332-1341. doi: 10.1053/j.gastro.2008.02.059

Kong, J. H., Yang, L., Dessaud, E., Chuang, K., Moore, D. M., Rohatgi, R., et al. (2015). Notch activity modulates the responsiveness of neural progenitors to sonic hedgehog signaling. Dev. Cell 33, 373-387. doi: 10.1016/j.devcel.2015. 03.005

Kool, M., Korshunov, A., Remke, M., Jones, D. T., Schlanstein, M., Northcott, P. A., et al. (2012). Molecular subgroups of medulloblastoma: an international metaanalysis of transcriptome, genetic aberrations, and clinical data of WNT, SHH, Group 3, and Group 4 medulloblastomas. Acta Neuropathol. 123, 473-484. doi: 10.1007/s00401-012-0958-8

Kool, M., Koster, J., Bunt, J., Hasselt, N. E., Lakeman, A., van Sluis, P., et al. (2008). Integrated genomics identifies five medulloblastoma subtypes with distinct genetic profiles, pathway signatures and clinicopathological features. PloS One 3, e3088. doi: 10.1371/journal.pone.0003088

Kool, M., Jones, D. T., Jager, N., Northcott, P. A., Pugh, T. J., Hovestadt, V., et al. (2014). Genome sequencing of SHH medulloblastoma predicts genotyperelated response to smoothened inhibition. Cancer Cell 25 (3), 393-405. doi: 10.1016/j.ccr.2014.02.004

Kopan, R., and Ilagan, M. X. (2009). The canonical Notch signaling pathway: unfolding the activation mechanism. Cell 137, 216-233. doi: 10.1016/j. cell.2009.03.045

Kosinski, C., Li, V. S., Chan, A. S., Zhang, J., Ho, C., Tsui, W. Y., et al. (2007). Gene expression patterns of human colon tops and basal crypts and BMP antagonists as intestinal stem cell niche factors. Proc. Natl Acad. Sci. U. S. A. 104, 1541815423. doi: 10.1073/pnas.0707210104

Krebs, L. T., Iwai, N., Nonaka, S., Welsh, I. C., Lan, Y., Jiang, R., et al. (2003). Notch signaling regulates left-right asymmetry determination by inducing Nodal expression. Genes Dev. 17, 1207-1212. doi: 10.1101/gad.1084703

Kuang, S. Q., Fang, Z., Zweidler-McKay, P. A., Yang, H., Wei, Y., GonzalezCervantes, E. A., et al. (2013). Epigenetic inactivation of Notch-Hes pathway in human B-cell acute lymphoblastic leukemia. PloS One 8, e61807. doi: 10.1371/ journal.pone.0061807

Kumar, V., Palermo, R., Talora, C., Campese, A. F., Checquolo, S., Bellavia, D., et al. (2014). Notch and NF-kB signaling pathways regulate miR-223/FBXW7 axis in T-cell acute lymphoblastic leukemia. Leukemia 28, 2324-2335. doi: 10.1038/ leu.2014.133

Larsson, J., Blank, U., Helgadottir, H., Bjornsson, J. M., Ehinger, M., Goumans, M. J., et al. (2003). TGF-beta signaling-deficient hematopoietic stem cells have normal self-renewal and regenerative ability in vivo despite increased proliferative capacity in vitro. Blood 102, 3129-3135. doi: 10.1182/blood-2003-04-1300

Le Bousse-Kerdiles, M. C., Chevillard, S., Charpentier, A., Romquin, N., Clay, D., Smadja-Joffe, F., et al. (1996). Differential expression of transforming growth factor-beta, basic fibroblast growth factor, and their receptors in CD34+ hematopoietic progenitor cells from patients with myelofibrosis and myeloid metaplasia. Blood 88, 4534-4546.

Lee, J., Platt, K. A., Censullo, P., and Ruiz i Altaba, A. (1997). Gli1 is a target of Sonic hedgehog that induces ventral neural tube development. Development 124, 2537-2552.

Lee, J. H., Song, S. Y., Kim, M. S., Yoo, N. J., and Lee, S. H. (2018). Intratumoral heterogeneity of frameshift mutations of GLI1 encoding a Hedgehog signaling protein in colorectal cancers. Pathol. Oncol. Res. 24, 477-481. doi: 10.1007/ s12253-017-0272-9

Li, X., Deng, W., Lobo-Ruppert, S. M., and Ruppert, J. M. (2007). Glil acts through Snail and E-cadherin to promote nuclear signaling by beta-catenin. Oncogene 26, 4489-4498. doi: 10.1038/sj.onc.1210241

Li, Y., Hibbs, M. A., Gard, A. L., Shylo, N. A., and Yun, K. (2012). Genome-wide analysis of N1ICD/RBPJ targets in vivo reveals direct transcriptional regulation of Wnt, SHH, and hippo pathway effectors by Notch1. Stem Cells 30, 741-752. doi: $10.1002 /$ stem. 1030
Lindemann, R. K. (2008). Stroma-initiated hedgehog signaling takes center stage in B-cell lymphoma. Cancer Res. 68, 961-964. doi: 10.1158/0008-5472. CAN-07-5500

Lindstrom, E., Shimokawa, T., Toftgard, R., and Zaphiropoulos, P. G. (2006). PTCH mutations: distribution and analyses. Human Mutat. 27, 215-219. doi: 10.1002/humu.20296

Liu, S., Dontu, G., Mantle, I. D., Patel, S., Ahn, N. S., Jackson, K. W., et al. (2006). Hedgehog signaling and Bmi-1 regulate self-renewal of normal and malignant human mammary stem cells. Cancer Res. 66, 6063-6071. doi: 10.1158/00085472.CAN-06-0054

Logan, C. Y., and Nusse, R. (2004). The Wnt signaling pathway in development and disease. Annu. Rev. Cell Dev. Biol. 20, 781-810. doi: 10.1146/annurev. cellbio.20.010403.113126

Lopes, S. S., Lourenco, R., Pacheco, L., Moreno, N., Kreiling, J., and Saude, L. (2010). Notch signalling regulates left-right asymmetry through ciliary length control. Development 137, 3625-3632. doi: 10.1242/dev.054452

MacDonald, B. T., Tamai, K., and He, X. (2009). Wnt/beta-catenin signaling: components, mechanisms, and diseases. Dev. Cell 17, 9-26. doi: 10.1016/j. devcel.2009.06.016

Maeda, O., Kondo, M., Fujita, T., Usami, N., Fukui, T., Shimokata, K., et al. (2006). Enhancement of GLI1-transcriptional activity by beta-catenin in human cancer cells. Oncol. Rep. 16, 91-96. doi: 10.3892/or.16.1.91

Mar, B. G., Amakye, D., Aifantis, I., and Buonamici, S. (2011). The controversial role of the Hedgehog pathway in normal and malignant hematopoiesis. Leukemia 25, 1665-1673. doi: 10.1038/leu.2011.143

Mastronardi, F. G., Dimitroulakos, J., Kamel-Reid, S., and Manoukian, A. S. (2000). Co-localization of patched and activated sonic hedgehog to lysosomes in neurons. Neuroreport 11, 581-585. doi: 10.1097/00001756-20000228000030

McAuliffe, S. M., Morgan, S. L., Wyant, G. A., Tran, L. T., Muto, K. W., Chen, Y. S., et al. (2012). Targeting Notch, a key pathway for ovarian cancer stem cells, sensitizes tumors to platinum therapy. Proc. Natl Acad. Sci. U. S. A. 109, E2939E2948. doi: 10.1073/pnas.1206400109

Merchant, A. A., and Matsui, W. (2010). Targeting Hedgehog-a cancer stem cell pathway. Clin. Cancer Res. 16, 3130-3140. doi: 10.1158/1078-0432. CCR-09-2846

Micci, F., Panagopoulos, I., Tjonnfjord, G. E., Kolstad, A., Delabie, J., Beiske, K., and Heim, S. (2007). Molecular cytogenetic characterization of $\mathrm{t}(14 ; 19)(\mathrm{q} 32 ; \mathrm{p} 13)$, a new recurrent translocation in B cell malignancies. Virchows Arch. 450, 559565. doi: 10.1007/s00428-007-0407-6

Michaud, E. J., and Yoder, B. K. (2006). The primary cilium in cell signaling and cancer. Cancer Res. 66, 6463-6467. doi: 10.1158/0008-5472.CAN-06-0462

Moustakas, A., Souchelnytskyi, S., and Heldin, C. H. (2001). Smad regulation in TGF-beta signal transduction. J. Cell Sci. 114, 4359-4369.

Mullor, J. L., Dahmane, N., Sun, T., and Ruiz i Altaba, A. (2001). Wnt signals are targets and mediators of Gli function. Curr. Biol. 11, 769-773. doi: 10.1016/ S0960-9822(01)00229-9

Mumm, J. S., and Kopan, R. (2000). Notch signaling: from the outside in. Dev. Biol. 228, 151-165. doi: 10.1006/dbio.2000.9960

Napolitano, M., Marfia, G. A., Vacca, A., Centonze, D., Bellavia, D., Di Marcotullio, L., et al. (1999). Modulation of gene expression following long-term synaptic depression in the striatum. Brain Res. Mol. Brain Res. 72, 89-96. doi: 10.1016/ S0169-328X(99)00213-2

Naylor, T. L., Greshock, J., Wang, Y., Colligon, T., Yu, Q. C., Clemmer, V., et al. (2005). High resolution genomic analysis of sporadic breast cancer using arraybased comparative genomic hybridization. Breast Cancer Res. 7, R1186-R1198. doi: $10.1186 /$ bcr 1356

Nessling, M., Richter, K., Schwaenen, C., Roerig, P., Wrobel, G., Wessendorf, S. et al. (2005). Candidate genes in breast cancer revealed by microarray-based comparative genomic hybridization of archived tissue. Cancer Res. 65, 439-447.

Nilsson, M., Unden, A. B., Krause, D., Malmqwist, U., Raza, K., Zaphiropoulos, P. G., and Toftgard, R. (2000). Induction of basal cell carcinomas and trichoepitheliomas in mice overexpressing GLI-1. Proc. Natl Acad. Sci. U. S. A. 97, 3438-3443. doi: 10.1073/pnas.97.7.3438

Nitzki, F., Zibat, A., Frommhold, A., Schneider, A., Schulz-Schaeffer, W., Braun, and T., Hahn, H. (2011). Uncommitted precursor cells might contribute to increased incidence of embryonal rhabdomyosarcoma in heterozygous Patched1-mutant mice. Oncogene 30, 4428-4436. doi: 10.1038/onc.2011.157 
Northcott, P. A., Nakahara, Y., Wu, X., Feuk, L., Ellison, D. W., Croul, S., et al. (2009). Multiple recurrent genetic events converge on control of histone lysine methylation in medulloblastoma. Nat. Genet. 41, 465-472. doi: 10.1038/ng.336

Noubissi, F. K., Goswami, S., Sanek, N. A., Kawakami, K., Minamoto, T., Moser, A., et al. (2009). Wnt signaling stimulates transcriptional outcome of the Hedgehog pathway by stabilizing GLI1 mRNA. Cancer Res. 69, 8572-8578. doi: 10.1158/00085472.CAN-09-1500

Nusslein-Volhard, C., and Wieschaus, E. (1980). Mutations affecting segment number and polarity in Drosophila. Nature 287, 795-801. doi: 10.1038/287795a0

Okuyama, R., Tagami, H., and Aiba, S. (2008). Notch signaling: its role in epidermal homeostasis and in the pathogenesis of skin diseases. J. Dermatol. Sci. 49, 187-194. doi: 10.1016/j.jdermsci.2007.05.017

Oliver, T. G., Grasfeder, L. L., Carroll, A. L., Kaiser, C., Gillingham, C. L., Lin, S. M., et al. (2003). Transcriptional profiling of the Sonic hedgehog response: a critical role for N-myc in proliferation of neuronal precursors. Proc. Natl Acad. Sci. U. S. A. 100, 7331-7336. doi: 10.1073/pnas.0832317100

Ormestad, M., Astorga, J., Landgren, H., Wang, T., Johansson, B. R., Miura, N., and Carlsson, P. (2006). Foxf1 and Foxf2 control murine gut development by limiting mesenchymal Wnt signaling and promoting extracellular matrix production. Development 133, 833-843. doi: 10.1242/dev.02252

Palermo, R., Checquolo, S., Bellavia, D., Talora, C., and Screpanti, I. (2014). The molecular basis of notch signaling regulation: a complex simplicity. Curr. Mol. Med. 14, 34-44. doi: 10.2174/1566524013666131118105216

Palomero, T., Lim, W. K., Odom, D. T., Sulis, M. L., Real, P. J., Margolin, A., et al. (2006). NOTCH1 directly regulates c-MYC and activates a feed-forward-loop transcriptional network promoting leukemic cell growth. Proc. Natl Acad. Sci. U. S. A. 103, 18261-18266. doi: 10.1073/pnas.0606108103

Pardali, K., Kurisaki, A., Moren, A., ten Dijke, P., Kardassis, D., and Moustakas, A. (2000). Role of Smad proteins and transcription factor Sp1 in p21(Waf1/Cip1) regulation by transforming growth factor-beta. J. Biol. Chem. 275, 2924429256. doi: 10.1074/jbc.M909467199

Pearse, R. V., LS, Collier, MP, Scott, and Tabin, C. J. (1999). Vertebrate homologs of Drosophila suppressor of fused interact with the gli family of transcriptional regulators. Dev. Biol. 212, 323-336. doi: 10.1006/dbio.1999.9335

Pelullo, M., Quaranta, R., Talora, C., Checquolo, S., Cialfi, S., Felli, M. P., et al. (2014). Notch3/Jagged1 circuitry reinforces notch signaling and sustains T-ALL. Neoplasia 16, 1007-1017. doi: 10.1016/j.neo.2014.10.004

Petrova, R., and Joyner, A. L. (2014). Roles for Hedgehog signaling in adult organ homeostasis and repair. Development 141, 3445-3457. doi: 10.1242/dev.083691

Pierrat, M. J., Marsaud, V., Mauviel, A., and Javelaud, D. (2012). Expression of microphthalmia-associated transcription factor (MITF), which is critical for melanoma progression, is inhibited by both transcription factor GLI2 and transforming growth factor-beta. J. Biol. Chem. 287, 17996-18004. doi: 10.1074/jbc.M112.358341

Poschl, J., Bartels, M., Ohli, J., Bianchi, E., Kuteykin-Teplyakov, K., Grammel, D., et al. (2014). Wnt/beta-catenin signaling inhibits the Shh pathway and impairs tumor growth in Shh-dependent medulloblastoma. Acta Neuropathol. 127, 605-607. doi: 10.1007/s00401-014-1258-2

Price, M. A., and Kalderon, D. (2002). Proteolysis of the Hedgehog signaling effector Cubitus interruptus requires phosphorylation by glycogen synthase kinase 3 and casein kinase 1. Cell 108, 823-835. doi: 10.1016/S0092-8674(02)00664-5

Qualtrough, D., Rees, P., Speight, B., Williams, A. C., and Paraskeva, C. (2015). The Hedgehog inhibitor cyclopamine reduces beta-catenin-Tcf transcriptional activity, induces E-cadherin expression, and reduces invasion in colorectal cancer cells. Cancers 7, 1885-1899. doi: 10.3390/cancers7030867

Quaranta, R., Pelullo, M., Zema, S., Nardozza, F., Checquolo, S., Lauer, D. M., et al. (2017). Mamll acts cooperatively with Gli proteins to regulate sonic hedgehog signaling pathway. Cell Death Dis. 8, e2942. doi: 10.1038/cddis. 2017.326

Radojcic, V., and Maillard, I. (2014). A jagged road to lymphoma aggressiveness. Cancer cell 25, 261-263. doi: 10.1016/j.ccr.2014.03.001

Raffel, C., Jenkins, R. B., Frederick, L., Hebrink, D., Alderete, B., Fults, D. W. (1997). Sporadic medulloblastomas contain PTCH mutations. Cancer Res. 57 (5), 842-845.

Ramalho-Santos, M., Melton, D. A., and McMahon, A. P. (2000). Hedgehog signals regulate multiple aspects of gastrointestinal development. Development 127, 2763-2772.
Reedijk, M., Odorcic, S., Zhang, H., Chetty, R., Tennert, C., et al. (2008). Activation of Notch signaling in human colon adenocarcinoma. Int. J. Oncol. $33,1223-1229$.

Regl, G., Neill, G. W., Eichberger, T., Kasper, M., Ikram, M. S., Koller, J., et al. (2002). Human GLI2 and GLI1 are part of a positive feedback mechanism in Basal Cell Carcinoma. Oncogene 21, 5529-5539. doi: 10.1038/sj.onc.1205748

Reifenberger, J., Wolter, M., Knobbe, C. B., Kohler, B., Schonicke, A., Scharwachter, C., et al. (2005). Somatic mutations in the PTCH, SMOH, SUFUH and TP53 genes in sporadic basal cell carcinomas. Br. J. Dermatol. 152, 43-51. doi: 10.1111/j.13652133.2005.06353.x

Reifenberger, J., Wolter, M., Weber, R. G., Megahed, M., Ruzicka, T., Lichter, P., et al. (1998). Missense mutations in SMOH in sporadic basal cell carcinomas of the skin and primitive neuroectodermal tumors of the central nervous system. Cancer Res. 58, 1798-1803.

Rimkus, T. K., Carpenter, R. L., Qasem, S., Chan, M., and Lo, H. W. (2016). Targeting the sonic hedgehog signaling pathway: review of smoothened and GLI inhibitors. Cancers 8, 22-45. doi: 10.3390/cancers8020022

Roberts, W. M., Douglass, E. C., Peiper, S. C., Houghton, P. J., and Look, A. T. (1989). Amplification of the gli gene in childhood sarcomas. Cancer Res. 49, 5407-5413.

Rodilla, V., Villanueva, A., Obrador-Hevia, A., Robert-Moreno, A., FernandezMajada, V., Grilli, A., et al. (2009). Jagged1 is the pathological link between Wnt and Notch pathways in colorectal cancer. Proc. Natl Acad. Sci. U. S. A. 106, 6315-6320. doi: 10.1073/pnas.0813221106

Rohatgi, R., Milenkovic, L., and Scott, M. P. (2007). Patched1 regulates hedgehog signaling at the primary cilium. Science 317, 372-376. doi: 10.1126/science. 1139740

Rosati, E., Sabatini, R., Rampino, G., Tabilio, A., Di Ianni, M., Fettucciari, K., et al. (2009). Constitutively activated Notch signaling is involved in survival and apoptosis resistance of B-CLL cells. Blood 113, 856-865. doi: 10.1182/ blood-2008-02-139725

Ross, D. A., and Kadesch, T. (2001). The notch intracellular domain can function as a coactivator for LEF-1. Mol. Cell. Biol. 21, 7537-7544. doi: 10.1128/ MCB.21.22.7537-7544.2001

Rowbotham, N. J., Hager-Theodorides, A. L., Furmanski, A. L., and Crompton, T. (2007). A novel role for Hedgehog in T-cell receptor signaling: implications for development and immunity. Cell cycle 6, 2138-2142. doi: 10.4161/cc.6.17.4644

Rusert, J. M., Wu, X., Eberhart, C. G., Taylor, M. D., and Wechsler-Reya, R. J. (2014). SnapShot: medulloblastoma. Cancer cell 26940-40, e1. doi: 10.1016/j. ccell.2014.11.015

Rustighi, A., Zannini, A., Tiberi, L., Sommaggio, R., Piazza, S., Sorrentino, G., et al. (2014). Prolyl-isomerase Pin 1 controls normal and cancer stem cells of the breast. EMBO Mol. Med. 6, 99-119. doi: 10.1002/emmm.201302909

Ryan, K. E., and Chiang, C. (2012). Hedgehog secretion and signal transduction in vertebrates. J. Biol. Chem. 287, 17905-17913. doi: 10.1074/jbc.R112.356006

Sasaki, H., Nishizaki, Y., Hui, C., Nakafuku, M., and Kondoh, H. (1999). Regulation of Gli2 and Gli3 activities by an amino-terminal repression domain: implication of Gli2 and Gli3 as primary mediators of Shh signaling. Development 126, 3915-3924.

Schreck, K. C., Taylor, P., Marchionni, L., Gopalakrishnan, V., Bar, E. E., Gaiano, N., and Eberhart, C. G. (2010). The Notch target Hes1 directly modulates Gli1 expression and Hedgehog signaling: a potential mechanism of therapeutic resistance. Clin. Cancer Res. 16, 6060-6070. doi: 10.1158/1078-0432.CCR-10-1624

Sengupta, A., Banerjee, D., Chandra, S., Banerji, S. K., Ghosh, R., Roy, R., et al. (2007). Deregulation and cross talk among Sonic hedgehog, Wnt, Hox and Notch signaling in chronic myeloid leukemia progression. Leukemia 21, 949955. doi: 10.1038/sj.leu.2404657

Seoane, J., Pouponnot, C., Staller, P., Schader, M., Eilers, M., and Massague, J. (2001). TGFbeta influences Myc, Miz-1 and Smad to control the CDK inhibitor p15INK4b. Nat. Cell Biol. 3, 400-408. doi: 10.1038/35070086

Sheng, T., Li, C., Zhang, X., Chi, S., He, N., Chen, K., et al. (2004). Activation of the hedgehog pathway in advanced prostate cancer. Mol. Cancer 3, 29. doi: 10.1186/1476-4598-3-29

Shin, H. M., Minter, L. M., Cho, O. H., Gottipati, S., Fauq, A. H., Golde, T. E., et al. (2006). Notch1 augments NF-kappaB activity by facilitating its nuclear retention. EMBO J. 25, 129-138. doi: 10.1038/sj.emboj.7600902

Siegel, P. M., and Massague, J. (2003). Cytostatic and apoptotic actions of TGF-beta in homeostasis and cancer. Nat. Rev. Cancer 3, 807-821. doi: 10.1038/nrc1208 
Sikandar, S. S., Pate, K. T., Anderson, S., Dizon, D., Edwards, R. A., Waterman, M. L., et al. (2010). NOTCH signaling is required for formation and self-renewal of tumor-initiating cells and for repression of secretory cell differentiation in colon cancer. Cancer Res. 70, 1469-1478. doi: 10.1158/0008-5472.CAN09-2557

Singh, R. R., Kim, J. E., Davuluri, Y., Drakos, E., Cho-Vega, J. H., Amin, H. M., et al. (2010). Hedgehog signaling pathway is activated in diffuse large B-cell lymphoma and contributes to tumor cell survival and proliferation. Leukemia 24, 1025-1036. doi: 10.1038/leu.2010.35

Sinha, S., Singh, R. K., Alam, N., Roy, A., Roychoudhury, S., and Panda, C. K. (2008). Frequent alterations of hMLH1 and RBSP3/HYA22 at chromosomal 3 p22.3 region in early and late-onset breast carcinoma: clinical and prognostic significance. Cancer Sci. 99, 1984-1991. doi: 10.1111/j.1349-7006.2008.00952.x

Sisson, B. E., Ziegenhorn, S. L., and Holmgren, R. A. (2006). Regulation of Ci and $\mathrm{Su}(\mathrm{fu})$ nuclear import in Drosophila. Dev. Biol. 294, 258-270. doi: 10.1016/j. ydbio.2006.02.050

Smith, M. J., Beetz, C., Williams, S. G., Bhaskar, S. S., O'Sullivan, J., Anderson, B., et al. (2014). Germline mutations in SUFU cause Gorlin syndrome-associated childhood medulloblastoma and redefine the risk associated with PTCH1 mutations. J. Clin. Oncol. 32, 4155-4161. doi: 10.1200/JCO.2014.58.2569

Staal, F. J., Famili, F., Garcia Perez, L., and Pike-Overzet, K. (2016). Aberrant Wnt signaling in leukemia. Cancers 8, 78-93. doi: 10.3390/cancers8090078

Stasiulewicz, M., Gray, S. D., Mastromina, I., Silva, J. C., Bjorklund, M., Seymour, P. A., et al. (2015). A conserved role for Notch signaling in priming the cellular response to Shh through ciliary localisation of the key Shh transducer Smo. Development 142, 2291-2303. doi: 10.1242/dev.125237

Stecca, B., and Ruiz i Altaba, A. (2009). A GLI1-p53 inhibitory loop controls neural stem cell and tumour cell numbers. EMBO J. 28, 663-676. doi: 10.1038/ emboj.2009.16

Steg, A. D., Katre, A. A., Goodman, B., Han, H. D., Nick, A. M., Stone, R. L., et al. (2011). Targeting the notch ligand JAGGED1 in both tumor cells and stroma in ovarian cancer. Clin. Cancer Res. 17, 5674-5685. doi: 10.1158/1078-0432. CCR-11-0432

Stone, D. M., Murone, M., Luoh, S., Ye, W., Armanini, M. P., Gurney, A., et al. (1999). Characterization of the human suppressor of fused, a negative regulator of the zinc-finger transcription factor Gli. J. Cell Sci. 112 (Pt 23), 4437-4448.

Swartling, F. J., Grimmer, M. R., Hackett, C. S., Northcott, P. A., Fan, Q. W., Goldenberg, D. D., et al. (2010). Pleiotropic role for MYCN in medulloblastoma. Genes Dev. 24, 1059-1072. doi: 10.1101/gad.1907510

Sweeney, R. T., McClary, A. C., Myers, B. R., Biscocho, J., Neahring, L., Kwei, K. A., et al. (2014). Identification of recurrent SMO and BRAF mutations in ameloblastomas. Nat. Genet. 46, 722-725. doi: 10.1038/ng.2986

Syed, V. (2016). TGF-beta signaling in cancer. J. Cell. Biochem. 117, 1279-1287. doi: $10.1002 / j c b .25496$

Taeubner, J., Brozou, T., Qin, N., Bartl, J., Ginzel, S., Schaper, J., et al. (2018). Congenital embryonal rhabdomyosarcoma caused by heterozygous concomitant PTCH1 and PTCH2 germline mutations. Eur. J. Human Genet. 26, 137-142. doi: 10.1038/s41431-017-0048-4

Taipale, J., Cooper, M. K., Maiti, T., and Beachy, P. A. (2002). Patched acts catalytically to suppress the activity of Smoothened. Nature 418, 892-897. doi: 10.1038/nature00989

Takebe, N., Harris, P. J., Warren, R. Q., and Ivy, S. P. (2011). Targeting cancer stem cells by inhibiting Wnt, Notch, and Hedgehog pathways. Nat. Rev. Clin. Oncol. 8, 97-106. doi: 10.1038/nrclinonc.2010.196

Talora, C., Campese, A. F., Bellavia, D., Felli, M. P., Vacca, A., Gulino, A., et al. (2008). Notch signaling and diseases: an evolutionary journey from a simple beginning to complex outcomes. Biochim. Biophys. Acta 1782, 489-497. doi: 10.1016/j.bbadis.2008.06.008

Talora, C., Cialfi, S., Oliviero, C., Palermo, R., Pascucci, M., Frati, L., et al. (2006). Cross talk among Notch3, pre-TCR, and Tall in T-cell development and leukemogenesis. Blood 107, 3313-3320. doi: 10.1182/blood-2005-07-2823

Taylor, M. D., Liu, L., Raffel, C., Hui, C. C., Mainprize, T. G., Zhang, X., et al. (2002). Mutations in SUFU predispose to medulloblastoma. Nat. Genet. 31, 306-310. doi: 10.1038/ng916

Taylor, M. D., Zhang, X., Liu, L., Hui, C. C., Mainprize, T. G., Scherer, S. W., et al. (2004). Failure of a medulloblastoma-derived mutant of SUFU to suppress WNT signaling. Oncogene 23, 4577-4583. doi: 10.1038/sj.onc.1207605
Teglund, S., and Toftgard, R. (2010). Hedgehog beyond medulloblastoma and basal cell carcinoma. Biochim. Biophys. Acta 1805, 181-208. doi: 10.1016/j. bbcan.2010.01.003

Tetsu, O., and McCormick, F. (1999). Beta-catenin regulates expression of cyclin D1 in colon carcinoma cells. Nature 398, 422-426. doi: 10.1038/18884

Thayer, S. P., di Magliano, M. P., Heiser, P. W., Nielsen, C. M., Roberts, D. J., Lauwers, G. Y., et al. (2003). Hedgehog is an early and late mediator of pancreatic cancer tumorigenesis. Nature 425, 851-856. doi: 10.1038/nature02009

Thomas, W. D., Chen, J., Gao, Y. R., Cheung, B., Koach, J., Sekyere, E., et al. (2009). Patched 1 deletion increases N-Myc protein stability as a mechanism of medulloblastoma initiation and progression. Oncogene 28, 1605-1615. doi: 10.1038/onc.2009.3

Thompson, M. C., Fuller, C., Hogg, T. L., Dalton, J., Finkelstein, D., Lau, C. C., et al. (2006). Genomics identifies medulloblastoma subgroups that are enriched for specific genetic alterations. J. Clin. Oncol. 24, 1924-1931. doi: 10.1200/ JCO.2005.04.4974

Tottone, L., Zhdanovskaya, N., Carmona Pestana, A., Zampieri, M., Simeoni, F., Lazzari, S., et al. (2019). Histone modifications drive aberrant Notch3 expression/ activity and growth in T-ALL. Front. Oncol. 9, 198. doi: 10.3389/fonc.2019.00198

Ulloa, F., Itasaki, N., and Briscoe, J. (2007). Inhibitory Gli3 activity negatively regulates Wnt/beta-catenin signaling. Curr. Biol. 17, 545-550. doi: 10.1016/j. cub.2007.01.062

Vacca, A., Felli, M. P., Palermo, R., Di Mario, G., Calce, A., Di Giovine, M., et al. (2006). Notch 3 and pre-TCR interaction unveils distinct NF-kappaB pathways in T-cell development and leukemia. EMBO J. 25, 1000-1008. doi: 10.1038/ sj.emboj.7600996

van den Brink, G. R., Bleuming, S. A., Hardwick, J. C., Schepman, B. L., Offerhaus, G. J., Keller, J. J., et al. (2004). Indian Hedgehog is an antagonist of Wnt signaling in colonic epithelial cell differentiation. Nat. Genet. 36, 277-282. doi: $10.1038 /$ ng1304

Vargas Romero, P., Cialfi, S., Palermo, R., De Blasio, C., Checquolo, S., Bellavia, D., et al. (2015). The deregulated expression of miR-125b in acute myeloid leukemia is dependent on the transcription factor C/EBPalpha. Leukemia 29, 2442-2445. doi: 10.1038/leu.2015.117

Varjosalo, M., and Taipale, J. (2008). Hedgehog: functions and mechanisms. Genes Dev. 22, 2454-2472. doi: 10.1101/gad.1693608

Varnat, F., Duquet, A., Malerba, M., Zbinden, M., Mas, C., Gervaz, P. and Ruiz i Altaba, A., et al. (2009). Human colon cancer epithelial cells harbour active HEDGEHOG-GLI signalling that is essential for tumour growth, recurrence, metastasis and stem cell survival and expansion. EMBO Mol. Med. 1, 338-351. doi: 10.1002/emmm.200900039

Varnat, F., Siegl-Cachedenier, I., Malerba, M., Gervaz, P., and Ruiz i Altaba, A. (2010). Loss of WNT-TCF addiction and enhancement of HH-GLI1 signalling define the metastatic transition of human colon carcinomas. EMBO Mol. Med. 2, 440-457. doi: 10.1002/emmm.201000098

Varnum-Finney, B., Xu, L., Brashem-Stein, C., Nourigat, C., Flowers, D., Bakkour, S., et al. (2000). Pluripotent, cytokine-dependent, hematopoietic stem cells are immortalized by constitutive Notch1 signaling. Nat. Med. 6, 12781281. doi: $10.1038 / 81390$

Verrecchia, F., and Mauviel, A. (2007). Transforming growth factor-beta and fibrosis. World J. Gastroenterol. 13, 3056-3062. doi: 10.3748/wjg.v13.i22.3056

Vied, C., and Kalderon, D. (2009). Hedgehog-stimulated stem cells depend on non-canonical activity of the Notch co-activator Mastermind. Development 136, 2177-2186. doi: 10.1242/dev.035329

Vokes, S. A., Ji, H., McCuine, S., Tenzen, T., Giles, S., Zhong, S., et al. (2007). Genomic characterization of Gli-activator targets in sonic hedgehog-mediated neural patterning. Development 134, 1977-1989. doi: 10.1242/dev.001966

Wahl, S. M. (1994). Transforming growth factor beta: the good, the bad, and the ugly. J. Exp. Med. 180, 1587-1590. doi: 10.1084/jem.180.5.1587

Wall, D. S., Mears, A. J., McNeill, B., Mazerolle, C., Thurig, S., Wang, Y., et al. (2009). Progenitor cell proliferation in the retina is dependent on Notchindependent Sonic hedgehog/Hes1 activity. J. Cell Biol. 184, 101-112. doi: $10.1083 /$ jcb. 200805155

Wang, X. D., Inzunza, H., Chang, H., Qi, Z., Hu, B., Malone, D., Cogswell, J. (2013). Mutations in the hedgehog pathway genes SMO and PTCH1 in human gastric tumors. PloS One 8, e54415. doi: 10.1371/journal.pone.0054415

Weng, A. P., Millholland, J. M., Yashiro-Ohtani, Y., Arcangeli, M. L., Lau, A., Wai, C., et al. (2006). c-Myc is an important direct target of Notchl in T-cell 
acute lymphoblastic leukemia/lymphoma. Genes Dev. 20, 2096-2109. doi: 10.1101/gad.1450406

Wiemels, J., Wrensch, M., and Claus, E. B. (2010). Epidemiology and etiology of meningioma. J. Neuro-oncol. 99, 307-314. doi: 10.1007/s11060-010-0386-3

Wils, L. J., and Bijlsma, M. F. (2018). Epigenetic regulation of the Hedgehog and Wnt pathways in cancer. Crit. Rev. Oncol. Hematol. 121, 23-44. doi: 10.1016/j. critrevonc.2017.11.013

Wolfraim, L. A., Fernandez, T. M., Mamura, M., Fuller, W. L., Kumar, R., Cole, D. E., et al. (2004). Loss of Smad3 in acute T-cell lymphoblastic leukemia. N. Engl. J. Med. 351, 552-559. doi: 10.1056/NEJMoa031197

Wong, S. Y., and Reiter, J. F. (2008). The primary cilium at the crossroads of mammalian hedgehog signaling. Curr. Top. Dev. Biol. 85, 225-260. doi: 10.1016/S0070-2153(08)00809-0

Wood, L. D., Parsons, D. W., Jones, S., Lin, J., Sjoblom, T., Leary, R. J., et al. (2007). The genomic landscapes of human breast and colorectal cancers. Science 318, 1108-1113. doi: 10.1126/science. 1145720

Wu, L., Aster, J. C., Blacklow, S. C., Lake, R., Artavanis-Tsakonas, S., and Griffin, J. D. (2000). MAML1, a human homologue of Drosophila mastermind, is a transcriptional co-activator for NOTCH receptors. Nat. Genet. 26, 484-489. doi: $10.1038 / 82644$

Xie, G., Karaca, G., Swiderska-Syn, M., Michelotti, G. A., Kruger, L., Chen, Y., et al. (2013). Cross-talk between Notch and Hedgehog regulates hepatic stellate cell fate in mice. Hepatology 58, 1801-1813. doi: 10.1002/hep.26511

Xie, J., Murone, M., Luoh, S. M., Ryan, A., Gu, Q., Zhang, C., et al. (1998). Activating Smoothened mutations in sporadic basal-cell carcinoma. Nature 391, 90-92. doi: 10.1038/34201

Yang, X., Letterio, J. J., Lechleider, R. J., Chen, L., Hayman, R., Gu, H., et al. (1999). Targeted disruption of SMAD3 results in impaired mucosal immunity and diminished T cell responsiveness to TGF-beta. EMBO J. 18, 1280-1291. doi: 10.1093/emboj/18.5.1280

Yavropoulou, M. P., Maladaki, A., and Yovos, J. G. (2015). The role of Notch and Hedgehog signaling pathways in pituitary development and pathogenesis of pituitary adenomas. Hormones 14, 5-18. doi: 10.1007/BF03401377
Yoshikawa, K., Shimada, M., Miyamoto, H., Higashijima, J., Miyatani, T., Nishioka, M., et al. (2009). Sonic hedgehog relates to colorectal carcinogenesis. J. Gastroenterol. 44, 1113-1117. doi: 10.1007/s00535-009-0110-2

Yoshimoto, A. N., Bernardazzi, C., Carneiro, A. J., Elia, C. C., Martinusso, C. A., Ventura, G. M., et al. (2012). Hedgehog pathway signaling regulates human colon carcinoma HT-29 epithelial cell line apoptosis and cytokine secretion. PloS One 7, e45332. doi: 10.1371/journal.pone.0045332

Zavadil, J., and Bottinger, E. P. (2005). TGF-beta and epithelial-to-mesenchymal transitions. Oncogene 24, 5764-5774. doi: 10.1038/sj.onc.1208927

Zavadil, J., Cermak, L., Soto-Nieves, N., and Bottinger, E. P. (2004). Integration of TGF-beta/Smad and Jagged1/Notch signalling in epithelial-to-mesenchymal transition. EMBO J. 23, 1155-1165. doi: 10.1038/sj.emboj.7600069

Zi, Z., Chapnick, D. A., and Liu, X. (2012). Dynamics of TGF-beta/Smad signaling. FEBS Lett. 586, 1921-1928. doi: 10.1016/j.febslet.2012.03.063

Zinke, J., Schneider, F. T., Harter, P. N., Thom, S., Ziegler, N., Toftgard, R., et al. (2015). Beta-catenin-Gli1 interaction regulates proliferation and tumor growth in medulloblastoma. Mol. Cancer 14, 17. doi: 10.1186/s12943-015-0294-4

Zurawel, R. H., Allen, C., Chiappa, S., Cato, W., Biegel, J., Cogen, P., et al. (2000). Analysis of PTCH/SMO/SHH pathway genes in medulloblastoma. Genes Chromosomes Cancer 27, 44-51. doi: 10.1002/(SICI)1098-2264(200001)27: $1<44::$ AID-GCC6>3.0.CO;2-V

Conflict of Interest Statement: The authors declare that the research was conducted in the absence of any commercial or financial relationships that could be construed as a potential conflict of interest.

Copyright (C) 2019 Pelullo, Zema, Nardozza, Checquolo, Screpanti and Bellavia. This is an open-access article distributed under the terms of the Creative Commons Attribution License (CC BY). The use, distribution or reproduction in other forums is permitted, provided the original author(s) and the copyright owner(s) are credited and that the original publication in this journal is cited, in accordance with accepted academic practice. No use, distribution or reproduction is permitted which does not comply with these terms. 